\title{
A Transactional View of Property Rights
}

\author{
By Robert P. Merges ${ }^{t}$
}

\begin{abstract}
Property rights and contract law are two of our most basic legal categories. Many legal scholars describe what makes them different; this Article describes how they work together to promote economic exchange. Incorporating the insights of both "transaction cost" and "new property rights" economics, it identifies two crucial contributions that property rights make to real-world contracting: (1) precontractual liability, or protection for disclosure of sensitive information in the period leading up to contract formation; and (2) enforcement flexibility after a contract is executed, in the form of many subtle but important advantages that accrue to a contracting party who also holds a property right. This Article argues that property's "transactional" role is growing in importance, as the "new economy" ushers in a more transaction-intensive industrial structure featuring greater numbers of smaller, more specialized firms.
\end{abstract}

I think you can often learn more about how the economic system works by reading law books and cases in law books than you can by reading economics books because you do get descriptions of actual business practices which are difficult to explain.

-Ronald Coase ${ }^{1}$

(C) 2005 Robert P. Merges

$\dagger$ Wilson Sonsini Professor of Law and Technology UC Berkeley. Special thanks to Ashish Arora and Paul Heald for comments, and to the editors at BTLJ for their suggestions. The usual disclaimer applies.

1. Quoted in The Fire of Truth: A Remembrance of Law and Economics at Chicago, 1932-1970, 26 J.L. \& ECON. 163, 193 (Edmund W. Kitch ed.,1983). 


\section{TABle of ConTENTS}

I. INTRODUCTION

A. BRIEF ReVIEW Of THE ReleVANT Legal AND ECONOMICS LITERATURE 1480

B. EXPLORING THE PROPERTY-CONTRACT INTERFACE BY STUDYING Patent Licensing Cases

C. Property's Transactional Role 1487

II. PROPERTY RIGHTS AND PRECONTRACTUAL LIABILITY 1489

A. The Limitations of CONTRACtUAl SAFEguards Against OPPORTUNISM 1489

B. THE ROLE OF PROPERTY RIGHTS IN PRECONTRACTUAL

DISCLOSURES

1. The Precontractual "Field Effect" of Property Rights 1499

2. What Disclosures do Property Rights Encourage? Evidence from the Case Law

3. Patents as Precontractual Protection 1502

III. PROPERTY RIGHTS AND ENFORCEMENT FLEXIBILITY 1504

A. BREACH VERSUS INFRINGEMENT SUITS: STRATEGIC AND PRACTICAL ADVANTAGES OF INCREASED FLEXIBILITY 1505

1. Infringement Over Breach of Contract: Strategy and Sample Cases.

a) Contractual Privity....

b) Statute of Limitations 1509

2. Breach of Contract Over Infringement: Strategy and Sample Cases

B. SUMMARY: ENFORCEMENT FLEXIBILITY IS IN THE DETAILS 1513

IV. WHY SHOULD WE CARE ABOUT ALL THIS? THE TRANSACTION-INTENSIVE LANDSCAPE OF THE NEW ECONOMY

V. CONCLUSION 


\section{INTRODUCTION}

Property rights and contracts are two of our most fundamental legal concepts. They are usually thought of as freestanding, if not contrasting, legal categories. Theorists often invoke the limitations of contracts to illuminate the essential features of property rights. ${ }^{2}$ From this approach a rich and influential literature has emerged. The "legal entitlements" literature, for example, highlights the significance of differing default remedies-money damages in contracts, injunctions in property. Other writings emphasize the rationale for the limited categories of property entitlements, in comparison with the ability of contracting parties, to create almost limitless obligations. With some exceptions, commentators continue to analyze and discuss property and contract as opposing concepts and quite distinct legal categories. ${ }^{3}$

This Article is different. I am interested in an aspect of property rights mostly neglected by legal theorists: how they facilitate contracting. This "transactional" view is more in line with the views of economists who study property rights. These scholars write generally about the role of property rights in structuring bilateral exchange, describing how property rights solve transactional problems that contracts cannot. But the economics literature remains quite sketchy on exactly how property rights function to facilitate transactions. That is the unique domain of this Article. Here I describe how specific aspects of property law encourage the making of real-world deals. To this end, I bring a lawyer's eye for detail (sharpened by close attention to the intricate facts of actual transactions) to the economists' models of contracting in the presence of property rights.

2. See, e.g., Thomas W. Merrill \& Henry E. Smith, The Property/Contract Interface, 101 CoLUM. L. REV. 773 (2001); Thomas W. Merrill \& Henry E. Smith, Optimal Standardization in the Law of Property: The Numerus Clausus Principle, 110 YALE L.J. 1 (2000) [hereinafter Merrill \& Smith, Optimal Standardization].

3. For a stimulating exception, see Paul J. Heald, $A$ Transaction Cost Theory of Patent Law, 66 OHIO ST. L.J. 473 (2005). Heald argues that patents lower the costs of transferring information assets, lower the costs of producing information assets by resolving problems of team production, and facilitate production and long-term business planning by embodying information in an asset distinct from the claims and interests of its creators or transferors, or their creditors or successors-a feature known as "asset partitioning." 


\section{A. Brief Review of the Relevant Legal and Economics Literature}

The literature on property rights is approximately as old as law itself. One may say the same for contracts. The relationship between them, however, is another story. Though even early commentators recognized fundamental differences, not until the pioneering work of Wesley Hohfeld ${ }^{4}$ did we have a sophisticated understanding of how these basic legal categories compared. Hohfeld gave us an analytically sound framework that laid bare the essential features of property, contract, and indeed all legal entitlements. This served tolerably well until the 1970 s, when a more rigorous application of economic principles swept through legal theory. The pathbreaking conceptual taxonomy of Calabresi and Melamed's article on Property Rules, Liability Rules and Inalienability ${ }^{5}$ opened our eyes to a number of fresh problems, primarily the question of who is best qualified to place a value on legal entitlements.

Meanwhile, parallel lines of development were underway in economics. Although early economic writings evince an understanding of property's importance in economic activity, in-depth analysis of the law of property and its economic implications did not begin until the twentieth century. A sociologically-informed group of researchers known as the institutionalists showed interest first. But most economists recognize Ronald Coase as the scholar who revolutionized our thinking about the role of legal entitlements-including property rights-in economic exchange. Beyond question, Coase made foundational contributions in the early days of law and economics, for which he received a Nobel Prize in 1994. Yet the very generality of Coase's vision left open a number of important issues. Coase, for example, understood that property rights were essential to the structuring of transactions. He recognized that prospective parties to a transaction must be able to recognize who has which rights prior to the exchange. ${ }^{6} \mathrm{He}$ also famously postulated that, with zero transaction costs, it

4. Wesley Newcomb Hohfeld, Fundamental Legal Conceptions as Applied in Judicial Reasoning, 26 YALE L.J. 710 (1917) [hereinafter Hohfeld, Fundamental Legal Conceptions].

5. Guido Calabresi \& A. Douglas Melamed, Property Rules, Liability Rules, and Inalienability: One View of the Cathedral, 85 HARV. L. REV. 1089 (1972) [hereinafter Calabresi \& Melamed, Property Rules]. (1959):

6. R.H. Coase, The Federal Communications Commission, 2 J.L. \& ECON. 1, 14

[I]f no property rights were created in land, so that everyone could use a tract of land, it is clear that there would be considerable confusion and that the price mechanism could not work because there would not be any property rights that could be acquired. If one person could use a piece of land for growing a crop, and then another person could come 
did not matter who held which rights; parties would bargain to an efficient outcome regardless. ${ }^{7}$ But he was largely silent on the detailed ways that parties come together to bargain and write contracts in these exchange relationships. For Coase, all of this "private ordering" took place in the shadow of property rights endowments, to be sure. Nonetheless, exactly how this private ordering took place, and how the details of property rights affected the resulting contracts, did not concern him.

In the 1960 s and 1970 s, economists began to look more closely at property rights, with particular attention to specification issues. ${ }^{8}$ Why, they asked, do property rights extend to some activities but not others? Why do the contours of property rights change over time? The general idea that came from this approach was what might be termed a progressive model of the development of property rights: when economic assets become more valuable, society more tightly specifies property rights. Harold Demsetz wrote the canonical case study in this literature, when he described the effects of an increase in the value of beaver pelts in early colonial Quebec and Labrador. ${ }^{9}$ Native peoples in that region, who had traditionally ranged freely to hunt beavers, instigated a system of protoproperty rights in response to the overhunting that followed from an increase in the value of pelts. Demsetz described property rights as a solution to the costs of the older communal regime, which had been in place before beaver pelts became more valuable. Put another way, Demsetz said that the increased costs of a private property regime-which entails marking and enforcing boundaries, among other things - became worthwhile only after the value of the hunted animals went up.

Many scholars have applied Demsetz' theory. Some work retrospectively to explain changes over time, while others employ the progressive

along and build a house on the land used for the crop, and then another could come along, tear down the house, and use the space as a parking lot, it would no doubt be accurate to describe the resulting situation as chaos. But it would be wrong to blame this on private enterprise and the competitive system. A private-enterprise system cannot function unless property rights are created in resources, and, when this is done, someone wishing to use a resource has to pay the owner to obtain it. Chaos disappears; and so does the government except that a legal system to define property rights and to arbitrate disputes is, of course, necessary.

7. Ronald H. Coase, The Problem of Social Cost, 3 J.L. \& EcoN. 1 (1960).

8. For a retrospective, see PROPERTY RIGHTS: COOPERATION, CONFLICT, AND LAW (Terry L. Anderson \& Fred S. McChesney eds., 2003) [hereinafter Anderson \& McChesney, PROPERTY RIGHTS].

9. Harold Demsetz, Toward a Theory of Property Rights, 57 AM. ECON. REV. (PAPERS \& PROC.) 347, $351-53$ (1967). 
model to analyze contemporary policy problems. ${ }^{10}$ Though the applications vary widely, they share a common vision: property rights change dynamically with changes in the economy, typically expanding as the benefits of greater individual control come to outweigh higher specification and enforcement costs.

Absent from this vision, however, is a detailed discussion of how property rights facilitate contracting. As with writings descended from Coase, the Demsetzian literature addresses transactional issues on a high level of abstraction. Most of the attention focuses on the initial definition and grant of property rights, typically by a government. There is some sense of post-grant private ordering, in that resources covered by property rights are assumed to move toward their natural (highest value) use. But no attention is paid to the transactions themselves; rather, scholars see them as a series of frictionless resource transfers-routine, inevitable, unremarkable.

It was precisely this view of transactions that Oliver Williamson sought to overthrow. Far from taking for granted that assets move automatically to their highest-valued use, Williamson (and now many others) placed transactions at the center of his economic theory. Transaction cost economics (TCE), the field pioneered by Williamson, takes as its primary concern the problem of costs and hazards in the transfer of resources from one economic unit to another. ${ }^{11}$ One well-studied hazard arises when a contracting party must invest considerable amounts of money in things that do not have much value outside a particular contracting relationshipwhat Williamson calls "asset specialization." When this occurs, the beneficiary of the specialized investment gains considerable bargaining leverage over the investing party. Economic actors, according to TCE, are not shy about using this leverage. Indeed, the theory assumes widespread "opportunism," defined as calculated advantage-taking within the context of an exchange.

A now-standard finding of the TCE literature, both theoretical and empirical, is that in situations where opportunism is common, contracting parties typically do one of two things: they either construct "contractual

10. There are examples of both in Anderson \& McChesney, PROPERTY RIGHTS, supra note 8 .

11. Oliver E. Williamson, The Mechanisms of Governance 3 (1996) [hereinafter WILLIAMSON, MECHANISMS OF GOVERNANCE] ("The identification, explication, and mitigation of contractual hazards--which take many forms, many of which long went unremarked-are central to the exercise [of TCE]."); see also OLIVER E. WILLIAMSON, The Economic Institutions of CAPITAlism 175 (1985); Oliver E. Williamson, MARKETS AND HIERARCHIES: ANALYSIS AND ANTITRUST IMPLICATIONS (1975). 
safeguards" to protect against the risk of being taken advantage of (discussed infra in Section II.A); or they forego contracts altogether and bring high-opportunism exchange "in house" by integrating the two transacting parties in a single firm. (In the TCE parlance, integration substitutes managerial "hierarchy" for arm's-length contracting.) TCE scholars see integration as a solution to pervasive opportunism in exchange relationships, explaining, for example, why a maker of auto bodies was subsumed into General Motors in the early days of the auto industry.

But integration has its costs, most notably, the lassitude that comes over a formerly hard-working company when it suddenly finds itself absorbed into a large bureaucracy. ${ }^{12}$ Sometimes this is the only way to get things done given the presence of serious transactional hazards; but in other cases, parties can preserve the benefits of contracting by building in contractual safeguards to overcome the threat of opportunism. For example, one party to an exchange can surrender a "hostage," something of value, to the other. ${ }^{13}$ If the first party reneges on the deal, the second can keep the hostage. ${ }^{14}$ This arrangement makes performance of the original deal more likely. One example is a performance bond, such as in a construction contract. A building contractor has all sorts of ways to delay, cheat, or otherwise trouble a client who wants a new building. So the client requires the contractor to post a fixed amount of money in the form of a bond, which the client can seize if the contractor acts opportunistically. ${ }^{15}$ Hostages can take many forms besides a bond ${ }^{16}$ and contracting parties use many other mechanisms as well. But what ties them all together, in the eyes of TCE theory, is a common concern for reducing the risk of opportunism.

12. In TCE lingo, this is translated as "the loss of high-powered incentives" that are typically associated with arm's-length contracting. See WiLLIAMSON, MECHANISMS OF GOVERNANCE, supra note 11 , at 43.

13. See Williamson, MEChanisms Of GovernanCE, supra note 11, at 120; Oliver E. Williamson, Credible Commitments: Using Hostages to Support Exchange, 73 AM. ECON. REV. 519 (1983).

14. The issue is treated theoretically in WILLIAMSON, MECHANISMS OF GOVERNANCE, supra note 11 , at 129.

15. See Gerald Garvey, Money Transfers Versus Hostages as Guarantors of Contractual Performance, 14 INT'L REV. L. \& ECON. 245, 245 (1994) (citing international construction contracts as a classic example of a hostage situation).

16. See Howard A. Shelanski \& Peter G. Klein, Empirical Research in Transaction Cost Economics: A Review and Assessment, 11 J.L. ECON. \& ORG. 335, 345 (1995) (discussing the mutual specific investments required in many franchising contracts as an example of a hostage). 
The richly detailed case studies in this Article (Parts II and III) show convincingly that property rights can significantly reduce the risk of opportunism. Yet property rights play a distinctly minor role in TCE. Williamson includes the "hazards that accrue to weak property rights" in the list of "hazards with which transaction cost economics is concerned."17 Some other TCE researchers explain how property rights affect economic activity. ${ }^{18}$ But TCE theorists do not attend to the specific ways that contracting parties use property rights to guard against opportunism.

One newer branch of economics that does take property rights seriously is the "new property rights" (NPR) branch pioneered by Oliver Hart, Sanford J. Grossman, and John Moore. ${ }^{19}$ NPR takes as its starting point that many contracts are difficult to enforce-an aspect of what is known as "contractual incompleteness." ${ }^{20}$ A prime example is where contractual compliance is very difficult for a court to assess. Consider, for example, a contract where a "technology buyer" agrees to pay another firm (the "R\&D" firm) for research and development work. The contract can call on the R\&D firm to "work very hard" or the like, but it will be difficult for a court to determine later if the firm has lived up to its obligation. For ex-

17. Williamson, MEChANISMS OF GOVERNANCE, supra note 11 , at 14 .

18. David Teece, for example, has written of the importance of "appropriability" in firm organization. A leading article describes how the absence of effective intellectual property protection for some aspects of a business leads to strategic firm choices, such as (1) greater integration and (2) embedding weakly protected information in complementary assets that are themselves hard to duplicate. David Teece, Profiting from Technological Innovation: Implications for Integration, Collaboration, Licensing and Public Policy, 15 RES. POL'Y 285 (1986). And TCE economist Joanne Oxley finds in a series of studies that in economies with weak intellectual property protection, transactions are more often integrated in a firm or firm-like organization, because arm's-length contracting is more risky in the absence of reliable property rights. Joanne E. Oxley, Institutional Environment and the Mechanisms of Governance: The Impact of Intellectual Property Protection on the Structure of Inter-Firm Alliances, 38 J. ECON. BEHAV. \& ORG. 283 (1999); Joanne E. Oxley, Appropriability Hazards and Governance in Strategic Alliances: A Transaction Cost Approach, 13 J.L. ECON. ORG. 387 (1997).

19. See Sanford J. Grossman \& Oliver D. Hart, The Costs and Benefits of Ownership: A Theory of Vertical and Lateral Integration, 94 J. POL. ECON. 691 (1986) [hereinafter Grossman \& Hart, Ownership]; Oliver Hart \& John Moore, Property Rights and the Nature of the Firm, 98 J. POL. ECON. 1119 (1990). A good overview of NPR theory is Oliver Hart, Firms, CONTRACTS and FinanCIal STRUCTURe (1995) [hereinafter HART, FIRMS AND CONTRACTS]. For an in-depth application of NPR theory to intellectual property rights, see Robert P. Merges, Intellectual Property Rights, Input Markets, and the Value of Intangible Assets (Feb. 9, 1999) (unpublished manuscript), http://www.law. berkeley.edu/institutes/bclt/pubs/merges/iprights.pdf.

20. This means, generally speaking, that parties to a contract cannot specify all the possible outcomes in advance. For a rigorous treatment, see Oliver Hart \& John Moore, Foundations of Incomplete Contracts, 66 REV. ECON. STUD. 115 (1999). 
ample, a judge or jury with no knowledge of a complex technology could mistakenly conclude that an R\&D firm had been lax in its efforts. This might permit a technology buyer to gain the benefits of the R\&D firm's work without having to pay full price. Knowing it cannot rely on contract enforcement, the R\&D firm may be leery of entering into a contract in the first place. To solve the dilemma, the parties may rely on a legal device that operates effectively even when contracts are difficult to enforce: property rights. Giving the R\&D firm a property right in the results of its work permits it to make money even if the technology buyer reneges on the deal. In the parlance of NPR theory, a property right increases the R\&D firm's "outside option." 21 More generally, NPR models show that transactors can work around contractual incompleteness by assigning a property right before entering into a contract.

Economists have brought NPR theory to bear on a wide range of problems. For example, they have employed it to describe why firms contracting for R\&D services often assign any resulting patents to the R\&D firm. ${ }^{22}$ (This is basically the scenario used in the example in the prior paragraph.) Economist Ashish Arora and I apply NPR theory to show that property rights can enhance the viability of independent sellers in some situations. This permits some specialty goods to be sold by freestanding, independent firms, instead of being supplied by another division of a single, integrated firm. ${ }^{23}$

Despite its contributions, NPR theory has also been criticized. ${ }^{24}$ The key weakness of the theory stems from the formal models on which it stands. Insightful critiques point out the sensitivity of these models to cer-

21. In NPR models, the outside option is synonymous with the "no-trade payoff," the payoff from an investment in the event that a contemplated post-investment trade does not in fact take place. See HART, FIRMS AND ConTRACTS, supra note 19, at 43.

22. See Philippe Aghion \& Jean Tirole, The Management of Innovation, 109 Q.J. ECON. 1185 (1994) [hereinafter Aghion \& Tirole, The Management of Innovation].

23. See Ashish Arora \& Robert P. Merges, Specialized Supply Firms, Property Rights and Firm Boundaries, 13 INDUS. \& CORP. CHANGE 451 (2004); see also Notes and Comments, 14 INDUS. \& CORP. CHANGE No. 6 (forthcoming 2005) (four commentaries on Arora \& Merges, supra); Notes and Comments, 16 INDUS. \& CORP. CHANGE No. 1 (forthcoming 2006) (responses by Arora and Merges).

24. See, e.g., Aghion \& Tirole, The Management of Innovation, supra note 22 (applying NPR theory to R\&D contracts); Georg Noldeke \& Klaus M. Schmidt, Sequential Investments and Options to Own, 29 RAND J. ECON. 633 (1998) (criticizing and extending original NPR theory); Raghuram G. Rajan \& Luigi Zingales, Power in a Theory of the Firm, 113 Q.J. ECON. 387 (1998) (criticizing and extending original NPR theory). A small empirical literature reports tests of NPR theory. See, e.g., Josh Lerner \& Robert P. Merges, The Control of Technology Alliances: An Empirical Analysis of the Biotechnology Industry, 46 J. INDUS. ECON. 125 (1998). 
tain limiting assumptions. ${ }^{25}$ I do not intend to engage these debates here. My point is simply this: the somewhat brittle structure of the models that form the basis of NPR theory has led commentators to dismiss it too quickly. Property rights can be extremely effective in structuring certain transactions. Beyond the narrow and technical conditions of formal NPR theory, there are many real-world transactions in which comprehensive contracts are difficult to specify, write, and enforce. The deep legal default rights that accompany property ownership come strongly into play here. They make it safe for parties to enter contracts when virtually no other form of transactional safeguard would work as well. In other words, NPR's central contribution is its transactional approach to property rights.

From the point of view of transaction cost economics (TCE), described earlier, NPR's main insight can be stated this way: that property rights act as contractual safeguards. They are uniquely valuable in solving some problems of contractual incompleteness. This Article applies a joint NPR/TCE perspective to a detailed review of real-world contracting, making two important findings: (1) property rights facilitate the initial approach of potential bargaining partners, by providing "precontractual protection"; and (2) property rights substantially enhance the enforcement options of contracting parties, through a collection of discrete rules and doctrines.

\section{B. Exploring the Property-Contract Interface by Studying Patent Licensing Cases}

In analyzing the property-contract interface I have chosen to study intellectual property (IP) licensing cases, primarily those involving patents. In the past, this would have seemed a highly unorthodox move; before the 1990 s, virtually all property theorizing was based on examples from real property. ${ }^{26}$ But in recent years, legal theorists have discovered that IP is an equally fertile ${ }^{27}$ and in some cases, superior ${ }^{28}$ — source of insights.

On a practical level, case reports often provide extremely fine-grained information about negotiations and contract performance. Licensing cases are an ideal population to study because of the large volume of contracting

25. See, e.g., Bengt Holmstrom \& John Roberts, The Theory of the Firm Revisited, 12 J. ECON. PERSP. 73, 79 (1998).

26. See, e.g., Calabresi \& Melamed, Property Rules, supra note 5; Hohfeld, Fundamental Legal Conceptions, supra note 4.

27. See, e.g., Merrill \& Smith, Optimal Standardization, supra note 2; Carol M. Rose, Romans, Roads and Romantic Creators: Traditions of Public Property in the Information Age, 66 LAw \& CONTEMP. PROB. 89 (2003).

28. See, e.g., Michael A. Heller \& Rebecca S. Eisenberg, Can Patents Deter Innovation? The Anticommons in Biomedical Research, 280 SCIENCE 698 (1998). 
involving IP. This steady flow of legal disputes yields a rich sample to study. By my very rough count, approximately $4 \%$ of the 3,627 reported patent infringement decisions in one database were the result of failed negotiations or an alleged breach of an existing licensing agreement. ${ }^{29}$ of course, reported cases may not be representative of all cases for a number of reasons. But, even if it is a very loose approximation, the $4 \%$ figure tells us we are discussing a substantial subset of cases. Further, the cases matter for reasons beyond their numbers because they tell us something important about the role of property rights in contract negotiation and enforcement.

Finally, IP licensing is an intrinsically important area of the law. As more and more assets come to be covered by IP rights, and the volume of licensing transactions continues to grow (see infra Part IV), this body of law will grow in importance in the coming years.

\section{Property's Transactional Role}

Many rules, doctrines, and what I would call "basic legal attitudes" shape the interaction between property rights and contracting in the IP area. I have organized this vast and somewhat amorphous body of law into two major themes, in keeping with my primary interest in how law shapes economic exchange:

Precontractual Liability: ways in which property rights encourage disclosure of sensitive information during the negotiations leading up to a formal contract; and

Enforcement Flexibility: enhancements in the enforcement options available to contracting parties when their contracts center around property rights.

29. Here is my decidedly unscientific methodology: I used the district court (dct) database in Westlaw. I searched for the 2004 cases with "patent infringement" in the headnotes. There were 161. I then repeated the search, looking for an additional phrase indicative of a failed negotiation or breached licensing agreement-"trade secret," "misappropriation," "breach," and the like. There were 21 of these in 2004. I went through those 21 cases and found 7 that met my criteria: failed negotiations or a breached license agreement. I repeated the "patent infringement" search on the entire database (1944- February 2005), and found a total of 3,627 cases, and then searched again for cases with "patent infringement" and also "trade secret," "misappropriation," and the like. There were 403. On the (unsupported!) assumption that the same ratio that held for 2004 holds for the entire sample, I assumed that $1 / 3$ of these 403 were of the type I was searching for. That number is 134 , which is a bit less than $4 \%$ of 3627 . Q.E.D. (!!) 
The first topic, precontractual liability, is well understood in the contracts literature. Contracts typically do not become binding until final, formal assent is given to their terms by all parties to the bargain. But in the period leading up to the "closing of the deal," much valuable information may be exchanged on both sides. When a deal falls apart before consummation, aggrieved parties have used a number of legal theories to seek recovery for the value of information exchanged during negotiations. These lawsuits have had decidedly mixed results. Yet, a careful reading of patent infringement cases reveals that the contracts literature has overlooked the most effective form of precontractual liability: property rights. Again and again, I have found cases involving patent infringement where the facts reveal an earlier attempt at licensing. Often a misappropriation of trade secrets cause of action is added to these cases, but by far the most effective theory of recovery is that of patent infringement. Even when a misappropriation claim succeeds, a patent or patent application usually appears in the background, again demonstrating the important role of property rights in facilitating economic exchange. This broad assortment of cases demonstrates conclusively the crucial role that property rights play in creating incentives to make precontractual disclosures, and hence, in structuring economic exchange generally.

To the second major topic I have attached the label "enforcement flexibility." This phrase pulls together under one heading a disparate collection of rules, doctrines, and scattered cases that collectively enhance the position of property holders when contractual disputes break out. For example, patent licensors can usually choose to enforce their bargains either by bringing a state law action sounding in contract or a federal action for patent infringement. This sometimes translates into a choice between state and federal courts-a choice worth having for a number of practical reasons. State courts are far more expert in the application of contract law, given their much larger caseload in this area. But federal patent infringement actions can bring superior remedial options, including the possibility of treble damages and attorney fees. The freedom to choose among fora and causes of action also carries a host of additional advantages, ranging from a longer statute of limitations in patent actions to the fact that a state court action does not put the validity of a patent at risk.

Through a host of sometimes minor doctrines, both substantive and procedural, patent holders are given significant advantages in the enforcement of contractual bargains. These advantages add up. They enhance the bargaining power and post-breach options of a contracting party. Taken together, they represent an important additional reason why property rights facilitate contracting. By increasing the strategic options of a 
contracting party, they encourage bargaining and exchange. Just as in the case of precontractual liability, these features of property rights foster transactions-the backbone of economic activity.

\section{PROPERTY RIGHTS AND PRECONTRACTUAL LIABILITY}

\section{A. The Limitations of Contractual Safeguards Against Opportunism}

Contract law is founded upon mutual agreement. Unless and until parties mutually agree, there is no contract-and, hence, no basis for legal liability. This fact is the mainspring of legal "assent": an offer without acceptance gives the offeror nothing and a purported acceptance with no valid offer gives the offeree nothing. Indeed, the fabric of contract lawfrom consideration to remedies-is shot through with indications of the importance of assent.

Assent has proven to be a durable mechanism for determining when legal liability attaches. Although there are of course gray areas, it is generally a useful bright line rule. But like many such rules, it comes at a cost. In cases where parties must exchange valuable information in order to achieve assent, liability under breach of contract principles may attach too late in the process to encourage the optimal amount of disclosure.

Sometimes negotiating parties do not have to share much information to strike a deal. A "spot market" purchase of some standard commoditywheat or corn, for instance-works like that. Other cases are different. Potential transactors must sometimes relate a good deal of information during the course of contract negotiations. This is especially true where the seller is selling a complex asset whose features and qualities are difficult for the buyer to ascertain. The seller must explain the features of the asset, often by disclosing information about how it is made, how it performs under various tests, and so on. Likewise, where the buyer is purchasing an input that is to be used as part of a larger assembly or process, the buyer must disclose some details about its overall operation so the seller can be sure the asset in question will work for its intended purpose.

Time and again in intellectual property cases there is evidence that, during negotiations to sell a business, license a patent, or the like, the parties have exchanged valuable information. Sellers or licensors in particular often must disclose details concerning a new technology in order to interest a buyer and in order to justify the price and other terms requested by the seller. A seller who does not disclose at least some information is ask- 
ing the buyer to purchase "a pig in a poke." This has not been lost on economists. Most pertinent is the work of economics Nobelist Kenneth Arrow. Over forty years ago, Arrow posited what has since come to be known as Arrow's information paradox: ${ }^{30}$ information cannot be evaluated by a buyer until it is disclosed, but then the buyer has no reason to pay for it because he or she already has it. ${ }^{31}$ (Arrow made this observation in the context of a discussion of the economics of patents-anticipating at the broad theoretical level the discussion of Part II below.)

Courts have not been blind to this; in response, they have developed an amorphous body of law known as "precontractual liability." Courts have applied various doctrines under this heading to find liability of one sort or another before a formal contract is signed. But as we shall see, none of these doctrines provide reliable protection during precontractual negotiations. ${ }^{32}$ That is where property rights come in-as we shall see in Section II.B below.

30. See Kenneth J. Arrow, Economic Welfare and the Allocation of Resources for Invention, in THE RATE AND DIRECTION OF INVENTIVE ACTIVITY: ECONOMIC AND SOCIAL FACTORS 609, 615 (Richard R. Nelson, Nat'l Bureau of Econ. Research ed., 1962). It is not referred to as "Arrow's paradox," because then it might be confused with another of Arrow's pathbreaking concepts-his "voting paradox," also known as "vote cycling." See JoSEPHINE T. ANDREWS, WhEN MAJORITIES FAIL: THE RuSSIAN PARLIAMENT, 1990-1993 $70-73$ (2002).

31. See Micro Data Base Sys., Inc. v. Dharma Sys., Inc., 148 F.3d 649, 657 (7th Cir. 1998 ) in which a software developer released copies of its program design to a project partner as part of an overall effort to sell software to a large customer, Unisys. Writing for the court, Judge Posner explained:

[A] commercial secret rarely has value if it is known only to one person. Others must be let in on the secret and the remaining secrecy preserved by contracts forbidding disclosure to still others who might exploit it commercially to the harm of the secret holder. The [software] could not be sold without giving the ultimate buyer, Unisys, a chance to inspect it.

Id.

32. The classic contribution here is E. Allen Farnsworth, Precontractual Liability and Preliminary Agreements: Fair Dealing and Fair Negotiations, 87 ColUM. L. REV. 217 (1987) [hereinafter Farnsworth, Precontractual Liability]. Some recent contracts scholarship aspires to overthrow the traditional "mutual assent" benchmark, and install a more nuanced regime of legal liability that would slowly bind parties over time during negotiations; but courts have not yet caught wind of this. See Lucian Arye Bebchuk \& Omri Ben-Shahar, Precontractual Reliance, 30 J. LEGAL STUD. 423 (2001); Omri BenShahar, Contracts Without Consent: Exploring a New Basis for Contractual Liability, 152 U. PA. L. REV. 1829 (2004); see also Symposium, Freedom from Contract, 2004 WIS. L. REV. 261 (2004). But see Ronald J. Mann, Contracts-Only With Consent, 152 U. PA. L. REV. 1873 (2004) (criticizing these proposals on pragmatic, doctrinal grounds). 
Most of the theories of precontractual liability are rooted in either promissory estoppel or some form of restitution. Promissory estoppel can be avoided by the simple expedient of not making any promises. Alternatively, where the parties have disclosed valuable information in the course of negotiations which later collapse, restitution has been an effective ground of recovery in some cases. ${ }^{33}$ Yet as the cases show, restitution suffers from a number of defects. The bulk of authority provides that, for a disclosure to be compensable, the disclosing party must have made the disclosure with the expectation of compensation. This foundational principle of restitution finds expression in the body of law most usually applied to these circumstances: trade secrecy, via the requirement of a "confidential relationship." When the facts indicate that a disclosure was not made in confidence, which they often do, there is no recovery for misappropriation of trade secrets. ${ }^{34}$

A series of cases concerning sale-of-business disclosures highlights the problematical features of conventional precontractual liability. One line of authority holds that negotiations in this setting are assumed to be conducted under a veil of confidentiality; hence disclosures are protected by trade secret law. ${ }^{35}$ Another, including some more recent cases, disagrees. These authorities find either no confidential relationship or no proof that the information disclosed was used in a way proscribed by trade secret law. ${ }^{36}$ Even cases which recognize confidentiality as a general rule often

33. Farnsworth, Precontractual Liability, supra note 32, at 223-24 (discussing the exemplary case of Earhart v. William Low Co., 25 Cal. $3 d 503$ (1979)).

34. For example, many cases hold that no confidential relationship is established when negotiating a distributorship agreement, even though valuable information may be disclosed in this setting. See, e.g., In re Dippin' Dots Patent Litig., 249 F. Supp. 2d 1346, 1377 (N.D. Ga. 2003).

35. See Cloud v. Standard Packaging Corp., 376 F.2d 384 (7th Cir. 1967); Hoeltke v. C.M. Kemp Mfg. Co., 80 F.2d 912, 922-23 (4th Cir. 1936) (restitution theory); Booth v. Stutz Motor Car Co. of Am., 56 F.2d 962 (7th Cir. 1932). Cf. Lucini Italia Co. v. Grappolini, No. 01 C 6405, 2003 WL 1989605 (N.D. Ill. 2003) (finding liability against consultant who misappropriated business opportunity offered by plaintiff).

36. See Omnitech Int'l, Inc. v. Clorox Co., 11 F.3d 1316 (5th Cir. 1994) (unsuccessful suit by seller of line of business against potential buyer who later bought competitor); Besly-Welles Corp. v. Balax, Inc., 291 F. Supp. 328, 346 (E.D. Wis. 1968) (discussing disclosures to potential investor or buyer of business: "The plaintiffs have failed to demonstrate that a confidential relationship existed or was contemplated by the parties. Therefore, the plaintiffs have not sustained their burden of proof that the defendants appropriated trade secrets."), aff'd in'rel. part sub nom Bendix Corp. v. Balax, Inc., 421 F.2d 809, 818 (7th Cir. 1970); see also Expansion Plus Inc. v. Brown-Forman Corp., 132 F.3d 1083 (5th Cir. 1998) (finding no ongoing confidential relationship arose from negotiations between software development company and another company that was interested in potentially acquiring rights in the software and promoting it commercially); In re 
find no confidential relationship under the facts presented. ${ }^{37}$ In any event, this issue is often a very close question. ${ }^{38}$ The upshot is that, despite the occasional upwelling of a restitutionary impulse, a rational person cannot rely on trade secret law to protect sensitive disclosures made at the precontractual stage of negotiations.

Even if a disclosing party can establish the presence of a confidential relationship, he or she must clear other hurdles to recovery. For one, the recipient of the disclosure may prove that the parties expressly agreed not to be bound by any undertaking short of a final, formal contract. ${ }^{39}$ In ef-

Dippin' Dots, 249 F. Supp. 2d at 1377 (stating that Uniform Trade Secrets Act, promulgated in 1995 and now adopted in twenty states, categorically excludes cases based on "implied duty of confidentiality").

37. See, e.g., Cloud, 376 F.2d at 384.

Where the facts show that a disclosure is made in order to further a particular relationship, a relationship of confidence may be implied, e.g. disclosure to a prospective purchaser to enable him to appraise the value of the secret, disclosure to a prospective lender to assure him of the prospects of the borrower's business, disclosure to agent, partner, or joint adventurer. Here, however, no relationship between the parties existed prior to or at the time of the disclosure, and although [the parties] had several discussions at later dates, of the problems involved, we find no dealing from which a relationship of confidence is reasonably to be implied.

Id. at 388-89 (footnote omitted); see also Pachmayr Gun Works, Inc. v. Olin Mathieson Chem. Corp. Winchester W. Div., 502 F.2d 802, 808 (9th Cir. 1974) ("[T]he courts will consider the factual circumstances of each case on an individual basis, to determine whether a confidential relationship may reasonably be implied.").

38. Cf. Burten v. Milton Bradley Co., 763 F.2d 461, 464 (1st Cir. 1985) (noting existence of confidential relationship is "so close a question in this case," ultimately reversing trial judge's grant of JNOV motion after jury verdict in favor of plaintiff, and therefore imposing liability for breach of confidence).

39. See Farnsworth, Precontractual Liability, supra note 32, at 257. Kearns also noted:

It is, quite simply, incredible that on the basis of two contacts three days apart [that plaintiff] ... formed with a mammoth, multi-national corporation a relationship of trust and confidence completely contrary to the plain language of a waiver [prohibiting reliance on a confidential relationship] he admits to having voluntarily signed ... . Even assuming, arguendo, that such a relationship had come into being in the three days before the first waiver was signed, the Court cannot but conclude that plaintiff's right to rely thereon was effectively terminated when the waiver form was first presented to him, for at that point he was put on notice of defendant's position and could have taken appropriate action. This the plaintiff did not do; instead, he signed the first waiver then and similar ones on two subsequent occasions. 
fect, parties can (and do) contract out of precontractual liability. In addition, the recipient of the information may be able to show the absence of other elements necessary to establish recovery for misappropriation of trade secrets-that the disclosing party did not take reasonable precautions to protect against widespread dissemination of the information, for example, ${ }^{40}$ that the information in question was never actually disclosed, ${ }^{41}$ or that the "disclosee" did not make use of the information in a way that violated trade secret law. ${ }^{42}$ The lesson from the cases is this: the parties may transmit a good deal of useful information during negotiations, but many uses of the information are not actionable.

A case in point is Omnitech International, Inc. v. Clorox Co. ${ }^{43} \mathrm{Om}-$ nitech was trying to sell its insecticide line of business to Clorox. During preliminary negotiations, Omnitech claimed that it disclosed much useful information to Clorox, about both the details of its products and the insecticide business generally. Clorox signed a nondisclosure agreement and an option to purchase Omnitech, but later acquired one of Omnitech's competitors instead. The Fifth Circuit upheld dismissal of Omnitech's claim for misappropriation of trade secrets. The court acknowledged that there

Kearns v. Ford Motor Co., 203 U.S.P.Q. 884, 888 (E.D. Mich. 1978) (footnote omitted); see also Cargill, Inc. v. Sears Petroleum \& Transp. Corp., 334 F. Supp. 2d 197, 245 (N.D.N.Y. 2004) (rejecting summary judgment in favor of disclosee, but noting that disclosee sent a letter prior to the meeting in which the disclosure occurred providing: "Our agreement to meet with you is contingent on your acknowledgment that no confidential information or otherwise proprietary information shall be exchanged."); cf. HirschChemie, Ltd. v. Johns Hopkins Univ., 36 U.S.P.Q.2d 1395, 1398 (4th Cir. 1985) (unpublished) (finding preliminary negotiations, including an exchange of letters, did not create a binding license agreement nor even an implied-in-fact contract); Pleatmaster, Inc., v. Consol. Trimming Corp., 111 U.S.P.Q. 124 (N.Y. Sup. Ct. 1956) (finding that defendant has valid defense to contract suit for royalties where defendant informed patentee/licensor it would not pay royalties until a contract was signed).

40. It is the court's opinion that the plaintiffs should have regarded [defendant's agent] as a potential competitor. The plaintiffs did not take reasonable precautions which would prevent him from becoming a competitor if a satisfactory arrangement could not be worked out with [plaintiffs]. Viewing [defendant's agent] as a potential competitor, the plaintiffs should have taken steps to insure the confidentiality of the information given to him.

Besly-Welles, 291 F. Supp. at 346.

41. See Heyman v. AR. Winarick, Inc., 325 F.2d 584, 588-90 (2d Cir. 1963) (finding that although confidential relationship existed during negotiations over the sale of a business, plaintiff never disclosed secret product formula or ingredients to defendant).

42. Id at a90-91 (holding customer information given to prospective buyer of business during negotiations qualified for trade secret protection, but defendant made no actionable use of the information).

43. 11 F.3d 1316 (5th Cir. 1994). 
may well have been a confidential relationship between the prospective buyer and seller in this case due to the nondisclosure agreement, but emphasized that Omnitech had not proven that Clorox used or disclosed Omnitech's information. Omnitech witnesses testified that Clorox must have made "use" of the Omnitech information in evaluating its bid for the competitor insecticide company. But the court stated that "to sustain a trade secrets action under the 'use' prong of the statutory definition of 'misappropriation,' a plaintiff must necessarily demonstrate that the defendant received some sort of unfair trade advantage."44 Thus, although the education that Omnitech provided was no doubt valuable, simply making Clorox smarter about the market for insecticides was not enough to trigger liability under trade secret law. ${ }^{45}$ The same pattern holds in related areas of the law as well. ${ }^{46}$

A case involving an invention in the aluminum processing industry provides another example of the limitations of pre-contractual liability theories. In Howell v. ALCOA, ${ }^{47}$ two inventors had developed an improved version of a common tool used in the aluminum industry. Representatives of ALCOA visited one of the inventors in his workshop to view a prototype and discuss a potential supply arrangement. The ALCOA officials were noncommittal, however. When a suspiciously similar design later turned up in use at ALCOA's factory, the inventors sued for precontractual liability under various theories. Unfortunately for them, the court held (partly on the basis of tape recordings made at the time of the meeting) that the officials involved clearly signaled their unwillingness and inability to enter into a formal contract or to commit ALCOA in any way. According to the court:

44. Id. at 1325 .

45. Two years later the Eighth Circuit followed Omnitech in a case involving essentially identical facts. Sip-Top, Inc. v. Ekco Group, Inc., 86 F.3d 827 (8th Cir. 1996).

46. Speaking of the closely analogous situation where an independent contractor is hired to assist in the work of a corporate employer, a treatise writer states:

Where independent contractors are employed, a duty of nondisclosure may be inadequate protection for the trade secret holder. It is often difficult to establish that unauthorized use occurred even if the contractor subsequently engages in competitive activity. Presumably, a contractor is selected because of its capability, especially in reference to design or production work. During the course of the contract, this capability may be enhanced by accumulated experience. Following termination of the original contract, the independent contractor will seek to use these capabilities and experience for its own purposes.

RAYMOND T. NIMMER, THE LAW OF COMPUTER TECHNOLOGY $\S 3: 28$ (2004).

47. 8 F. Supp. 2d 1012 (E.D. Tenn. 1997). 
[The ALCOA official] made it evident to [plaintiff-inventor] that he ... did not have the authority to enter into the contract which [the inventor] sought. [The official] discussed with [the inventor] the process of reaching some agreement with ALCOA in terms of "steps," one being determining whether the purchasing department would be willing to contract out for [the invention], and another being the obtaining of a price quotation from [the inventor] for consideration. . . . It is clear that [the official] contemplated that there would not be any binding agreement between [the inventor] and ALCOA until there was a written contract signed by the parties. ${ }^{48}$

$A L C O A$ illustrates well the problems that potential suppliers, such as the inventors in this case, face when beginning the process of disclosing and negotiating with a potential buyer. The inventors did not know that the ALCOA employee they were dealing with did not have authority to bind the company-a classic agency problem in contracting. Even if he could have, he signaled that no binding agreement was as yet contemplated. These obstacles proved fatal to the various contract-based theories of recovery that the two inventors had relied on. Without a property right, in a situation where preliminary negotiations did not produce a contract, the seller was left without any legal recourse.

\section{B. The Role of Property Rights in Precontractual Disclosures}

If precontractual disclosures were rare, the uncertainty in this area would not amount to much. But the truth is quite the opposite. In many cases, in particular where something new and untried is the subject of contract negotiations, much of value is disclosed. So how does a disclosing party cope? In this Section we see one effective solution: by owning property rights.

Property rights are often characterized by their effect on "strangers"; they are conventionally spoken of as being "good against the world." This is without doubt one of their most distinctive features. It flows from the in rem nature of property rights: legal relations follow from the res, the thing, and not from any preexisting relationship between parties. In fact, property rights in a sense create a legal relationship. This distinguishes them immediately from contracts, which as we have seen, bind only the specific parties that assent to their terms.

48. Id. at 1015 .

49. See, e.g., Thomas W. Merrill \& Henry E. Smith, The Property/Contract Interface, 101 COLUM. L. REV. 773 (2001). 
But the emphasis on universality —on being good against all comersobscures the role of property rights in the structuring of bilateral exchange. In the negotiation period leading up to the signing of a contract, property rights play an absolutely crucial role. Case after case mentions the disclosure of sensitive information during the precontractual stage, often under the protective cloak of a patent or other property right. So while property rights are indeed good against the world, I want to emphasize one crucial slice of the world-negotiating partners-which has been overlooked.

The case law demonstrates what I mean. In Celeritas Techs., Ltd. v. Rockwell Int'l Corp., ${ }^{50}$ for example, plaintiff Celeritas, having developed an advanced technique for correcting errors in modem transmissions, entered into negotiations with Rockwell, the dominant manufacturer of modems. After seven months of negotiations, the parties failed to conclude a formal joint business arrangement. ${ }^{51}$ Rockwell later began selling a product based on similar technology. ${ }^{52}$ Akin to Celeritas is Medtronic, Inc. v. Mine Safety Appliances Co. ${ }^{53}$ There, the sales agent for a subsidiary of Mine Safety disclosed technical information to medical pacemaker manufacturer Medtronic, an important buyer of Mine Safety's lithium/iodine $(\mathrm{Li} / \mathrm{I})$ batteries. The parties engaged in "technology exchanges in furtherance of developing $\mathrm{Li} / \mathrm{I}$ cells for pacemaker use," 54 which eventually resulted in a joint research and development agreement, and, ultimately an attempt by Medtronic to make the batteries itself, cutting Mine Safety out of the picture. ${ }^{55}$ A final example comes from Monolith Portland Midwest Co. v. Kaiser Aluminum \& Chemical Corp., ${ }^{56}$ a case involving technology for treating high-temperature brick kilns. The opinion in the case provides particularly rich details regarding the sorts of routine technical disclosures made in advance of a licensing transaction. The court recites numerous detailed disclosures regarding technical features of kiln construction, in particular techniques for attaching the kiln lining to the outer section of the kiln. Detailed testimony relates in-depth conversations the parties had to solve problems in kiln operation. After licensing negotiations broke down,

50. 150 F.3d 1354 (Fed. Cir. 1998).

51. Id. at $1356-57$.

52. Celeritas had obtained a patent on its technology. Although the patent was later invalidated, Rockwell was found liable for violation of a written nondisclosure agreement entered into at the beginning of negotiations. This general phenomenon-disclosures made under the protection of a patent or patent application-is discussed infra at Section III.A. 2 .

53. 468 F. Supp. 1132 (D. Minn. 1979).

54. Id. at 1136.

55. Id.

56. 152 U.S.P.Q. 380 (C.D. Cal. 1967). 
Midwest later sued for both misappropriation of trade secrets and patent infringement. ${ }^{57}$

Many other cases reveal the same pattern of disclosures on the way to a final contract. ${ }^{58}$ Often, the parties agree to an interim contract designed to cover only the disclosure and negotiation period. (Because these contracts are perfunctory and incomplete, and designed merely to foster negotiation of the "real" contract, I treat them as part of the "precontractual" period.) These temporary contracts are of two types. One, usually written by a large company that wants to foreclose liability as much as possible, expressly rules out any form of precontractual liability. A recent case involving Lexmark, the computer printer company, falls into this category. ${ }^{59}$ Obviously if the parties agree that a final contract is required for any sort of contractual liability, a disclosing party has no way to recover if no such contract is ever signed. (That became painfully obvious to BDT Products, Inc., the other party in the Lexmark case.)

There is another type of interim contract, the nondisclosure agreement (NDA). These temporary contracts sometimes better protect the disclosing party. The parties typically sign an NDA at the outset of negotiations. It is designed to protect against disclosure, and sometimes use, of information disclosed during the negotiations-typically, information the negotiators consider trade secrets. NDAs are not intended to be final, binding con-

57. Id. at 424. Illustrating some of the shortcomings of relying on trade secret theories in this context, the court found that none of the plaintiff's disclosures amounted to trade secrets (for example, because they were based on the opinion of plaintiff's technical expert, and not backed up with hard data). See id. at 401 . The court also found that the negotiations were not in any event conducted in an "atmosphere of trust and confidence." Id. at 420 .

58. For a sampling of very recent cases, see for example, Kara Tech., Inc. v. Stamps.com Inc., No. 04 Civ. 8364(LMM), 2005 WL 323749, at *1 (S.D.N.Y. Feb. 8, 2005) (adjudicating a motion to transfer in case where patentee disclosed online stamp business technology to defendant in context of licensing negotiation where defendant broke off negotiations and later entered the market); Medtronic Vascular, Inc. v. Advanced Cardiovascular Sys., No. Civ. 98-80-SLR, 2005 WL 46553, at *2 (D. Del. Jan. 5, 2005) (including allegations regarding disclosure of intricate details of new post-surgical vascular "stent" in context of effort to "look[] for a partner to develop [plaintiff's] technology"); On-Line Techs., Inc. v. Bodenseewerk Perkin-Elmer GMBH, 386 F.3d 1133, 1135 (Fed. Cir. 2004) ("[Plaintiff On-Line Technologies asserted that] it had revealed its gas cell design to Perkin-Elmer scientists in anticipation of a possible business arrangement between the companies relating to On-Line's device."); $c f$. Ultra-Precision Mfg., Ltd. v. Ford Motor Co., 411 F.3d 1369, 1379-81 (Fed. Cir. 2005) (rejecting suit by consultant for restitution or joinder to buyer's patents, where consultant could not show that information disclosed to buyer was different from or more valuable than information in consultant's previously-issued and published patents).

59. BDT Prods., Inc. v. Lexmark Int'l Inc., 274 F. Supp. 2d 880 (E.D. Ky. 2003). 
tracts. They are usually limited in ways that hurt a disclosing party's chances of recovery later. For one thing, some sophisticated parties refuse to sign them. ${ }^{60}$ For another, they often excuse a "disclosee" from liability where the disclosed information is available elsewhere at the time of disclosure. This can provide a robust defense for the disclosee, who need only show that the information disclosed during the negotiations could have been acquired from some public domain source. Furthermore, enforcing these agreements is a highly fact-intensive exercise. To recover, the disclosing party must prove that certain specific information was disclosed, typically at a certain meeting, which may have happened some years before a deposition or trial. In short, NDAs involve nontrivial problems of proof. For these reasons, they are far less effective than final, formal agreements. Most business people know this; they know that even with a signed NDA, precontractual disclosures can be risky for the disclosing party. ${ }^{61}$ As we will see in the next Section, this explains why disclosing parties so often seek property rights.

60. John G. Petrovich, Funding a Computer Technology Startup, 547 PLI/PAT 769, 771 (1999) ("Most venture capitalists outright refuse, or resist strenuously, signing a confidentiality or nondisclosure agreement, claiming that it invites legal problems.").

61. See, e.g., Christopher D. David, Note, When a Promise is Not a Promise: Georgia's Law on Noncompete Agreements, as Interpreted by the Eleventh Circuit in Keener v. Convergys Corporation, Gives Rise to Comity and Federalism Concerns, $11 \mathrm{~J}$. INTELL. PROP. L. 395, 396 (2004) ("Thus, the express non-disclosure agreement is, at best, an incomplete protection against disclosure."). Another commentator states:

The problem with confidentiality agreements is that they are not always available to new or smaller firms, which have only limited access to legal counseling. ... There is also the problem of trying to protect the unknown-it may be impossible to define the trade secret at the outset of the ... relationship, because the underlying research and development has not yet been done. Scientists and engineers who understand the mercurial nature of the technology industry are reluctant to sign confidentiality agreements because they do not want to sacrifice their future mobility.

Miles J. Feldman, Comment, Toward a Clearer Standard of Protectable Information: Trade Secrets and the Employment Relationship, 9 HIGH TECH. L.J. 151, 181 (1994). 


\section{The Precontractual "Field Effect" of Property Rights}

Property rights are often said to be good against the world. The owner of a property right need not show any special relationship with a third party in order to have legal rights against that party. This is one of the sharpest points of contrast between contracts and property rights. One easy way to envision this aspect of property rights is to see them as creating a "field of legal protection" around an asset. ${ }^{62}$ Anyone who comes within a certain distance of the field is subject to it, even though he or she has not yet made actual contact with the asset's owner. The field protects the asset; it is this feature that makes the asset owner more confident about allowing the asset "out into the world," where it can be inspected by those who might want to contract with the asset's owner.

There is a natural contrast here with exchange based strictly on contract rights or exchange in the absence of property rights. A contract is a direct legal relationship between two discrete economic actors-much like a direct connection between two "nodes" on a network. Until the direct link is established, the two nodes remain independent; they have no legal duties toward one another. Generally speaking, the legal duties created by contract come into being only as a result of the contractual relationship. As a consequence, an asset that is to be transferred strictly by contract occupies a precarious position in the period leading up to the contract. Until the direct relationship is firmly established, the asset is at risk. Knowing this, asset owners will have to be much more careful about who has access to it, and under what circumstances. It is precisely these limitations on the pre-contractual dealings between parties that property rights overcome so effectively. The figures that follow illustrate these concepts.

62. Others have suggested that property rights may be viewed this way. For example, Merrill and Smith state:

When we encounter a thing that is marked in the conventional manner as being owned, we know that we are subject to certain negative duties of abstention with respect to that thing-not to enter upon it, not to use it, not to take it, etc. And we know all this without having any idea who the owner of the thing actually is. In effect, these universal duties are broadcast to the world from the thing itself.

Thomas W. Merrill \& Henry E. Smith, What Happened to Property in Law and Economics?, 111 YALE L.J. 357, 359 (2001). 


\section{A Contract Represents a Direct \\ "Node to Node" Connection \\ Betweeen Seller (S) and Buyer (B)}

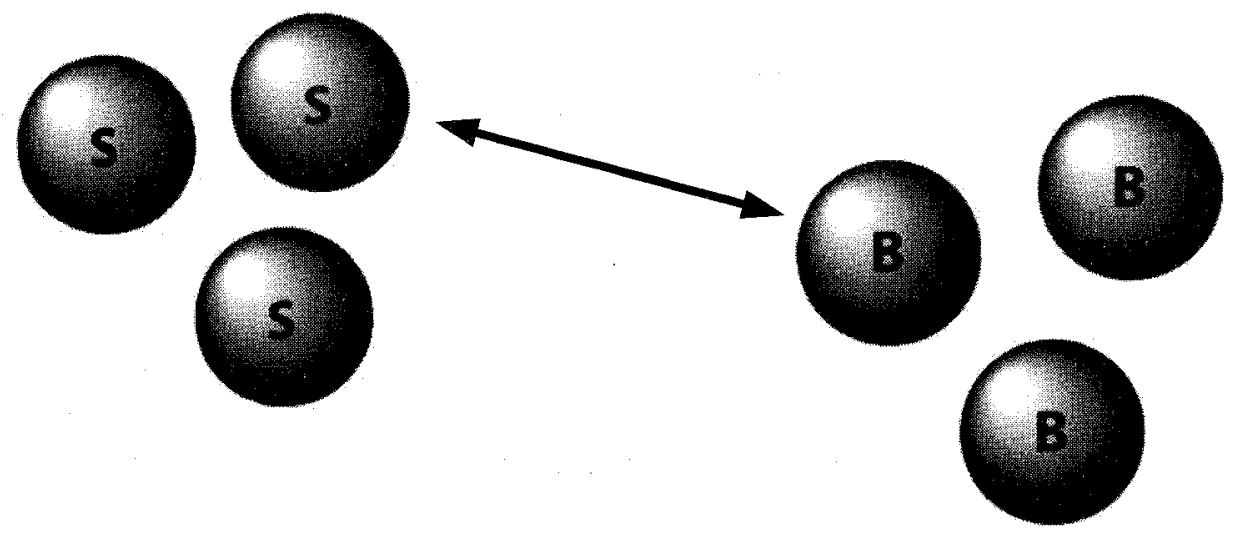

Property Rights Create a Legal "Field" Around an Information Asset (i), Protecting Seller (S) During Buyer's (B) Precontractual Evaluation

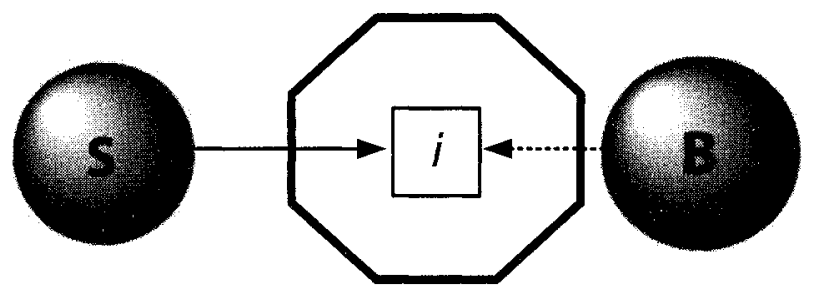

2. What Disclosures do Property Rights Encourage? Evidence from the Case Law

The case law shows that property rights - again, primarily patentsfacilitate disclosure of three types of information: (1) information contained in patent applications, which are kept secret for a substantial time after filing; (2) details related to an invention that are not disclosed in a patent or patent application; and (3) valuable but unpatented information beyond the boundaries of the patent. 
In the world of R\&D, timing is often crucial. This is evident from trade secret cases, where a common remedy is an injunction preventing a party from using misappropriated information for a certain period. This "headstart" period rightfully belongs to the trade secret's owner. By the same token, early receipt of information that will later be published in an issued patent (or, these days, a published patent application) may also be quite valuable. The cases reflect the importance of timing. Courts have, for instance, found liability for misappropriation of trade secret information later made public in an issued patent or other later-published information. The cases stress the advantage of early knowledge-information known by a party ahead of the general public. ${ }^{63}$

An issued patent usually does not disclose everything of value about an invention and the surrounding technology. Patent specifications are not "production handbooks"; much in the way of practical detail may lawfully be left out. And much of what is left out may be valuable. We know from detailed case studies of the development of specific technologies that the aggregate value of all the "minor" improvements, tweaks, and accumulated operational wisdom often exceeds the value of the basic invention itself. $^{64}$ This explains why so many patent license agreements also include a provision for the licensing of ancillary trade secrets and know-how. ${ }^{65}$ Indeed, some instructive articles from the economics literature suggest that the primary purpose of patents is to spearhead the transfer of the really valuable stuff - the associated unpatented information. ${ }^{66}$

There is also a broad category of information that is related, but ancillary, to the main disclosures of the patent. These data do not include details of the patented invention and its implementation but rather information about the business setting in which the technology may be employed, potential customers and their needs, and the like. This may grow out of market research done in connection with the actual $\mathrm{R} \& \mathrm{D}$, or it may come

63. See generally D. Kirk Jamieson, Just Deserts: A Model to Harmonize Trade Secret Injunctions, 72 NEB. L. REV. 515, 533-34 (1993) (collecting cases).

64. See, e.g., Samuel Hollander, The Sources of InCREASEd EFficiency: A STUDY OF DU PONT RAYON PLANTS (1965) (describing the primary importance of incremental process innovations in overall productivity improvement in nylon production technology):

65. See Edmund W. Kitch, The Nature and Function of the Patent System, 20 J.L. \& ECON. 265 (1977), reprinted in FOUNDATIONS OF INTELLECTUAL PROPERTY 140 (Robert P. Merges \& Jane C. Ginsburg eds., 2004).

66. See ASHISH ARORA, ANDREA Fosfuri \& Alfonso GAMBARDELla, MARKetS FOR TECHNOLOGY: THE ECONOMICS OF INNOVATION AND CORPORATE STRATEGY (2001); Ashish Arora, Contracting for Tacit Knowledge: The Provision of Technical Services in Technology Licensing Contracts, 50 J. DEV. ECON. 233, 246 (1996). 
from the experience of the R\&D firm itself. This can be very valuable information, whatever its form.

\section{Patents as Precontractual Protection}

As a case study, consider On-Line Technologies, Inc. v. Bodenseewerk Perkin-Elmer $G M B H .{ }^{67}$ A small company, On-Line, executed an agreement under which it disclosed details about its proprietary gas chromatograph technology to defendant Bodenseewerk Perkin Elmer (BPE), a potential customer and joint venture partner. The disclosing party, On-Line, was clearly expert in the technology area in question, ${ }^{68}$ and there are indications that BPE learned some valuable information. ${ }^{69}$ Yet the court ruled that On-Line had not proven that BPE misappropriated any trade secrets. Much of the court's discussion centers on a "battle of expert reports," which typifies this area of law. In the end, BPE's expert was more persuasive than On-Line's. ${ }^{70}$ Although the court held that On-Line had disclosed

67. 386 F.3d 1135, 1138 (Fed. Cir. 2004).

68. The On-Line Technologies case centered on U.S. Patent No. 5,440,143. One of the co-inventors listed on this patent, Robert M. Carangelo, is listed on numerous other patents and publications in this area. See, e.g., U.S. Patent No. RE35,872 (Aug. 18, 1998); Steven C. Bates et al., Fourier Transform Infrared Hadamard Tomography of Sooting Flames, 64 REV. SCI. INSTRUMENTS 1213 (1993). Carangelo also received an award from $R \& D$ Magazine as a participant in one of the top $100 \mathrm{R} \& D$ projects of 1994. See Reed Business Information Science Group, R\&D 100 Awards Archive: 1994, http://www.rdmag.com/rd100ach/RD100SearchResults.aspx?\&intYear=1994\&Type $=$ Y (listing Benchtop Emissometer Model 205 WB, produced by Advanced Fuel Research, Inc. and On-Line Technologies, Inc.).

69. For example, the Federal Circuit opinion states:

$[\mathrm{T}]$ he district court concluded that undisputed evidence showed that Perkin-Elmer did not begin to incorporate the features of On-Line's gas cell into its own product until 1996, after the issuance of [On-line's] patent. Although On-Line referred to evidence regarding PerkinElmer's conduct before the issuance of the ...patent, the district court held that none of that evidence was probative of misappropriation because the conduct in question all constituted legitimate evaluation of On-Line's product pursuant to the nondisclosure agreement entered into by On-Line and Perkin-Elmer in 1994.

On-Line Techs., 386 F.3d at 1141 . It is evident from this that BPE probably learned much about On-Line's technology during the negotiations; BPE simply did not incorporate this information into a useful product until after On-Line's patent issued. It seems unlikely that BPE "unlearned" the lessons it acquired from On-Line while "evaluating" the OnLine technology and then "re-learned" them by reading On-Line's patent when it later issued. The real point seems to be, once again, the elusive nature of trade secret misappropriation claims, which made it difficult for On-Line to carry its burden of proof regarding exactly how BPE used what it learned from On-Line in 1994.

70. See, e.g., id. at 1142 ("[BPE's expert] averred that he had learned nothing useful about On-Line's gas cell [when he visited the On-Line site during preliminary negotia- 
detailed information, much of the information was eventually disclosed in On-Line's patent when it issued ${ }^{71}$ or in a patent to a third party. ${ }^{72}$ In addition, BPE was engaged in "legitimate evaluation of On-Line's product pursuant to the nondisclosure agreement entered into by On-Line and Perkin-Elmer." 73

This aspect of the On-Line Technologies case demonstrates the weaknesses of trade secret law in protecting sensitive information. Fortunately for On-Line, it had another leg to stand on-patent infringement. While On-Line was negotiating with BPE, it was also pursuing a patent application, which issued as U.S. Patent No. 5,440,143 ("the '143 patent"), in $1995 .{ }^{74}$ The patent covered the very technology that On-Line was trying to license to BPE, namely, a method for increasing the length of the light path in a spectrometer gas cell. This patent made a major difference in the case. The Federal Circuit held that the patent claim at issue covered the products BPE sold after On-Line made its disclosures and the deal fell through. ${ }^{75}$ This gave On-Line an opportunity to recover against defendant BPE, notwithstanding its failure to prove that BPE misappropriated any On-Line trade secrets.

Patents give firms like On-Line an important weapon when precontractual negotiations break down. Knowing this, such a firm is more likely to pursue deals, making necessary disclosures along the way. Whatever the vagaries of proving a trade secret claim, if a negotiating partner such as BPE later enters the market with similar technology, the patent gives a firm like On-Line a chance to stop them, or at least to obtain some compensation. A patent in these circumstances thus undoubtedly makes it a bit easier for a firm like On-Line to enter into preliminary negotiations in the first place, and thus, a bit more likely that it will do so.

tions] that was not already evident from On-Line's nonconfidential marketing brochure. On-Line did not offer evidence to contradict [this] representation."); Id. at 1144 ("OnLine failed to address the assertions in [BPE's expert's] affidavit that the mirror array in the source assembly was "text-book". . . Although On-Line argues that the earlier device did not use a ceramic igniter as the energy source, there was no evidence before the district court that the difference in the energy source rendered On-Line's source assembly sufficiently distinct to constitute a protectable trade secret.").

71. Id. at 1141 .

72. Id. at 1143 .

73. Id.

74. The patent shows a filing date of February 25, 1994 and the On-Line case notes that the NDA was signed with BPE "in 1994." Id. at 1141.

75. Id. at 1140 (reversing district court claim construction, which had been basis of summary judgment of no infringement and remanding for further proceedings). 
Many other cases support this. Taken together, they show definitively that when a disclosing party has a patent, it has a much better chance of legal relief in the event his or her disclosure results in unauthorized market entry. The lesson, once again, is simple but important: property rights serve a crucial transactional role.

\section{PROPERTY RIGHTS AND ENFORCEMENT FLEXIBILITY}

A contracting party with a property right has far more options than one without. He or she can often bring suit for breach of contract or for infringement; before or after termination of a licensing contract; for contract or infringement damages, whichever is higher; in state or federal court; against parties or non-parties to the contract; and under a shorter (contracts) or longer (patent law) statute of limitations. Collectively, these advantages give a great deal of enforcement flexibility to property holders who have entered into contracts.

Notice that several of these advantages have a temporal dimension. These features are combined with the precontractual liability analysis of Part II, and depicted in the following figure, which compares the protections afforded sellers under contract with those made available by a property right:

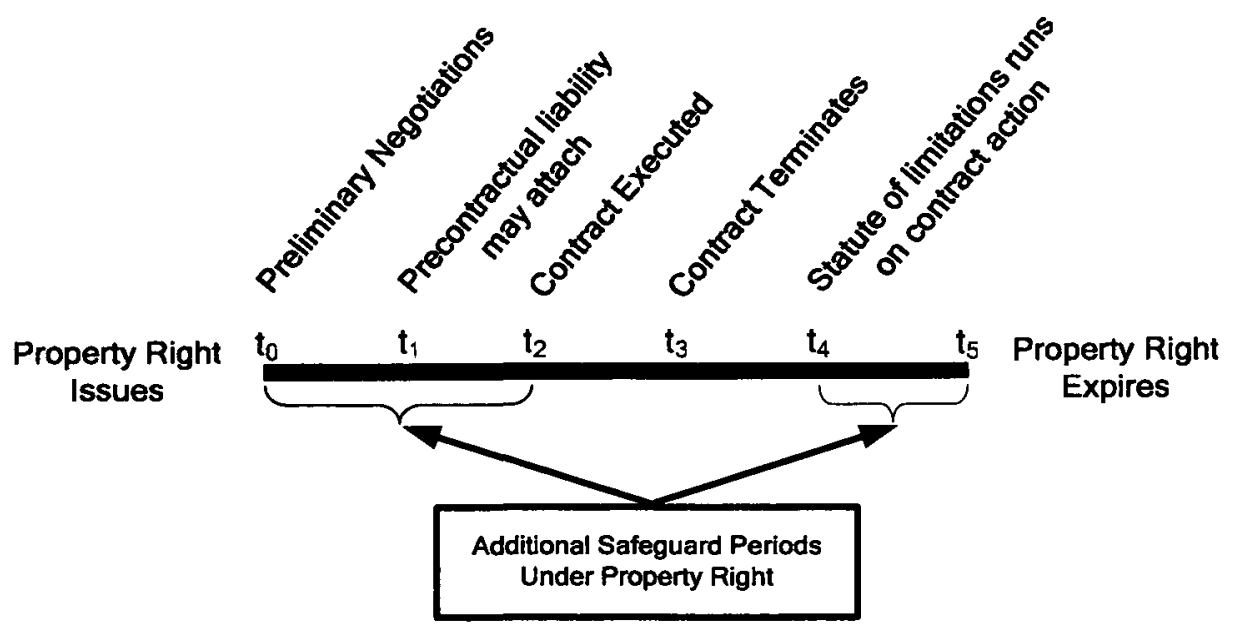

In this Part, we take up those advantages not primarily connected to the precontractual period: those that accrue from contract execution $\left(t_{2}\right.$ in Figure 5) to the running of the statute of limitations $\left(t_{5}\right)$. 


\section{A. Breach versus Infringement Suits: Strategic and Practical Advantages of Increased Flexibility}

Many of the enforcement options that come with property rights stem from the ability to sue for either breach of contract or infringement. ${ }^{76}$ (Without a property right, obviously, the only enforcement option is for breach of contract. ${ }^{77}$ ) Courts may require that the contracting party choose one or the other cause of action in a given lawsuit, ${ }^{78}$ but there is support for a party's right to pursue both types of cases in separate forums. ${ }^{79}$ The only requirement for federal jurisdiction is that the patentee must normally terminate the licensing agreement before filing suit. ${ }^{80}$

To see the practical advantages of this increased flexibility, it is best to consider some actual situations where parties chose one option over the other.

76. See Henry v. A.B. Dick Co., 224 U.S. 1 (1912); Dow v. United States, 36 Fed. Cl. 15 (1996).

77. See, e.g., Beghin-Say Int'l, Inc. v. Ole-Bendt Rasmussen, 733 F.2d 1568 (Fed. Cir. 1984) (finding that, where a firm that had commissioned research from a contract researcher sought to establish the enforceability of pre-invention assignment agreements, state contract law was its only recourse because with no federal property rights yet in existence, there was no federal court jurisdiction).

78. See, e.g., De Cew v. Union Bag \& Paper Corp., 57 F. Supp. 388 (D.N.J. 1944). Some cases speak in terms of an "election principle," as in "waive the tort, sue in assumpsit." Sims v. Jadin, 135 F. Supp. 917, 918 (E.D. Wis. 1955). This is usually applied to limit the plaintiff to one species of damage claim, however. See York v. Stromman, 105 Cal. App. 2d 586 (Ct. App. 1951). Despite this usage, there is no true "election" rule that applies in these cases. See Applera Corp. v. Illumina, Inc., 282 F. Supp. 2d 1120 (N.D. Cal. 2003) (denying defendant's motion to stay federal court action pending outcome of state contract lawsuit); cf. Del Ricchio v. Photochart, 124 Cal. App. 2d 301 (Ct. App. 1954) (holding that a suit under a patent license agreement does not automatically terminate the agreement, an event which would cut off right to sue for breach and trigger standing to sue for patent infringement).

79. See, e.g., Applera, 282 F. Supp. 2d at 1126 (refusing concurrent state and federal jurisdiction is "a rare occurrence").

80. Air Prods. \& Chems., Inc. v. Reichhold Chems., Inc., 755 F.2d 1559, 1562 (Fed. Cir. 1985); see also Gen-Probe, Inc. v. Vysis, Inc., 359 F.3d 1376 (Fed. Cir. 2004) (holding federal court does not have jurisdiction as long as licensing agreement is still in effect); Metabolite Labs, Inc. v. Lab. Corp. of Am. Holdings, 370 F.3d 1354 (Fed. Cir. 2004) (same); $c f$. Krantz v. Van Dette, 165 F. Supp. 776 (N.D. Ohio 1958) (holding posttermination events can only sound in patent law where licensor terminates the license itself). 


\section{Infringement Over Breach of Contract: Strategy and Sample Cases}

Sometimes, patent infringement litigation may have a higher expected payoff as compared to suit under a contract. A successful infringement suit may lead to higher damages for one of three reasons. Infringement damages, assessed after the termination of a licensing agreement, may exceed what the corresponding damages would have been in a suit for breach of contract. Second, a patentee can collect up to treble damages if there is proof that the infringement was willful. ${ }^{81}$ Finally, a successful patent infringement plaintiff may collect attorney fees in an "exceptional" case, while attorney fees are rarely awarded in contracts suits.

The situation in Wisconsin Alumni Research Foundation v. General Electric Co ${ }^{83}$ illustrates the point. WARF sued GE under two separate theories: breach of a licensing agreement and patent infringement for the period after WARF terminated the agreement. ${ }^{84}$ The district court awarded damages for breach of contract at the contract royalty rate of $2 \%$, but awarded infringement damages based on a $3.5 \%$ royalty rate. ${ }^{85}$ The upshot was that WARF benefited from advantageous patent law rules to obtain higher damages than it would have if it had sued only under the contract.

As the WARF case shows, there can be affirmative reasons to file suit for infringement rather than breach of contract. Beyond increased damages, another reason is that a plaintiff may face obstacles in mounting a breach of contract suit. There may be a lack of contractual privity with one or more of the defendants, for example, or the statute of limitations may bar a breach of contract suit. The issues are complex enough to merit a brief summary.

81. See 35 U.S.C. $\$ 284(2000)$.

82. See 35 U.S.C. $\$ 285(2000)$.

83. 880 F. Supp. 1266 (E.D. Wis. 1995).

84. The option to terminate a licensing agreement is an important aspect of the licensor's enforcement flexibility, because termination confers standing to sue for infringement. With an agreement still in effect, there can be only breach, and not infringement. See Gen-Probe, 359 F.3d at 1376. Sometimes specific contract language allows a licensor to terminate under certain circumstances. See, e.g., Nat'l Rejectors, Inc. v. A.B.T. Mfg. Corp., 184 F.2d 612 (7th Cir. 1950) (holding a patent licensing agreement provided for a right to terminate at the end of a specified period to cure inadequate performance under the agreement). In any event, material breach by the licensee justifies termination. See, e.g., Metabolite Labs, 370 F.3d at 1370.

85. WARF, 880 F. Supp. at 1274, 1276. 


\section{a) Contractual Privity}

Privity issues arise frequently in licensing cases. This issue is partly a result of the fact that many licensing negotiations involve more than two parties. ${ }^{86}$ These negotiations can be complex, with parties coming in and out of the picture over time. Any agreement that is finally reached may leave out one or more of the parties who were involved along the way. Firms may also participate in the development of a technology without ever intending to enter into a contract, typically by assisting one of the firms that is a party to the contract. ${ }^{87}$ Other cases grow out of distribution or supply chain arrangements in which one firm takes a product through one stage of production, and then hands it off to another firm further down the chain. ${ }^{88}$ This way of making things exposes each firm's technology to the risk of misappropriation by other firms down the chain-possibly including firms with whom they have no contract. Thus, in a production scenario where $A$ hands off to $B$ who hands off to $C, A$ and $B$ may have a contract, as well as $B$ and $C$, but perhaps not $A$ and $C$. Although there may be extensive dealings between $\mathrm{A}$ and $\mathrm{C}$, direct or indirect, there is no formal contractual relationship on which to base a legal claim. Patent infringement-a cause of action grounded in property rights-is the only option. $^{89}$

86. See, e.g., Lisle Corp. v. Edwards, 777 F.2d 693 (Fed. Cir. 1985) (involving three parties: designer/patentee, licensee, and licensee's customer); Ellison Educ. Equip., Inc. v. Chen, No. SACV02-1184-JVS(ANX), 2004 WL 3154592 (C.D. Cal. Dec. 21, 2004) (involving four primary parties: plaintiff, alleged co-inventor of technology growing out of a preliminary negotiation with eventual patentees/individual defendants; partner of patentees/individual defendants; and two companies with whom patentees/individual defendants had been doing business); Vapor Corp. v. Westcode Inc., 12 U.S.P.Q.2d 1218 (E.D. Pa. 1989) (involving three parties: trade secret owner, customer to whom it made disclosures, and competitor with whom customer allegedly shared disclosures).

87. See, e.g., Water Techs. Corp. v. Calco Ltd., 850 F.2d 660 (Fed. Cir. 1988) (regarding industry consultant representing potential licensee, who negotiated with patent owner and its licensee); Mixing Equip. Co., Inc. v. Innova-Tech, Inc., 9 U.S.P.Q.2d 1057 (E.D. Pa. 1988) (regarding patent licensor involved in multiple negotiations/disclosures with licensee and sub-licensee, where licensee makes allegations of trade secret disclosure by licensor to sub-licensee, and court dismissed trade secret cause of action by licensee against licensor and sub-licensee).

88. See, e.g., Key West Hand Print Fabrics, Inc. v. Serbin, Inc., 269 F. Supp. 605, 612 (S.D. Fla. 1966) (regarding a copyright case where the plaintiff fabric design firm sues a dress manufacturer for copyright infringement and unfair competition, but the unfair competition claim was dismissed because designer was not in privity with, and had no confidential relationship with, dress manufacturer).

89. Cf. RustEvader Corp. v. Cowatch, 842 F. Supp. 171, 172-73 (W.D. Pa. 1993), where the court, in a breach of contract case based on misappropriation of technology, observed: 
A case in point is Water Technologies Corp. v. Calco Ltd. ${ }^{90}$ A company called Aqua-Chem held rights in certain patents on resins used for water purification. Aqua-Chem granted an exclusive license to Water Technologies Corporation ("WTC"). An industry consultant named Gartner, acting on behalf of another company, approached Aqua-Chem to negotiate a license. Those negotiations broke off. Gartner then developed an alternative technology which he in turn licensed to a company called Calco. When Calco introduced a product that competed with WTC's, WTC brought suit for patent infringement (against Calco and Gartner) and misappropriation of trade secrets (against Calco, Gartner and WTC's licensor, Aqua-Chem). A district court found for the plaintiff on all counts. The Federal Circuit affirmed on the patent infringement claim, but reversed with respect to misappropriation, stating that "the facts here do not establish a claim by [WTC] distinct from its patent infringement claim ...."91 The problem was that Gartner was never party to the AquaChem/WTC license, nor was Gartner ever in a direct confidential relationship with WTC. Thus, even though Gartner learned of WTC's technology from a party with whom WTC was in a contractual relationship (AquaChem), WTC had no contractual privity with Gartner himself. The advantage of a property right in this context is manifest: without a patent, WTC would have had no tenable cause of action against Gartner and his licensee, Calco.

[Plaintiffs] fail to explain how this case arises solely out of a contract when one of the defendants, Cowatch Sr., is not a party to the contract in question. Plaintiffs have not cited any authority for such a proposition and have failed to address, in any way, defendant Cowatch Sr.'s presence in this action. In fact, plaintiffs do not assert anywhere in their complaint that Cowatch Sr. breached any contractual provision.

.... [And thus] the plaintiffs are seeking relief against ... a party not in privity with plaintiffs ....

90. 850 F.2d 660 (Fed. Cir. 1988).

91. We must agree with Calco and Gartner, therefore, that the district court erred in holding them liable to [WTC] for unfair competition [for example, misappropriation of trade secrets]. The only claim established by appellees against appellants is patent infringement under 35 U.S.C. $\S \S 271(a)$ and (b) (1982). Although a distinct cause of action for unfair competition may arise in a factual context which also gives rise to a patent infringement claim, the facts here do not establish a claim by [WTC] distinct from its patent infringement claim, which in itself is not a state unfair competition claim. Accordingly, we reverse the district court on this issue and remand with instructions to vacate the judgment to the extent that it upholds [WTC]'s unfair competition claim and includes an award of damages thereon.

Id. at 671 (footnote omitted). 


\section{b) Statute of Limitations}

Privity issues show that, compared to rights under contract, property rights are robust. Another doctrine demonstrates the same thing: the statute of limitations. Patent law's property-derived limitations period is quite long compared to the typical statute of limitations applied to contracts disputes. As with the other issues discussed earlier, this adds another small degree of flexibility to the property right holder engaged in a contractrelated dispute.

Contracts cases are usually subject to general civil suit limitations periods, which typically range from three to five years. ${ }^{92}$ Where a patent licensing dispute is cast as a contracts action, the contract statute of limitations applies. Misappropriation of trade secrets usually has a similarly short limitations period. ${ }^{93}$ While in many cases this is clearly an adequate period in which to bring a claim, sometimes a patentee-licensor shows more patience. Patent law indulges this option with a much longer limitations period, which the patentee can use to advantage simply by terminating the licensing agreement and bringing an action for patent infringement.

Properly speaking, there is no statute of limitations in the Patent Act. There is, however, a six year limit for collection of damages. The patentee must file suit within six years of the infringing activity in order to collect damages; otherwise, he or she can only get an injunction. ${ }^{94}$ The six year period also creates a presumption of laches. Plaintiffs who wait more than six years must introduce evidence to justify the long delay in filing suit; if they fail to persuade that delay was reasonable, their claim will be barred. ${ }^{95}$ On the other hand, ongoing licensing negotiations can provide a justification for delay, thus overcoming the presumption of laches. ${ }^{96}$ So in the context of interest to us-licensing situations-there can be a very

92. See, e.g., Studiengesellschaft Kohle mbH v. Hercules Inc., 18 U.S.P.Q.2d 1773, 1777 (D. Del. 1990) (citing Delaware's three year statute of limitations for contract actions, in context of patent licensing dispute).

93. See, e.g., Dual, Inc. v. Lockheed Martin Corp., 857 A.2d 1095, 1098, 1103-04 (Md. 2004) (citing three year limitations period for trade secret action in Maryland and discussing various tolling theories).

94. 35 U.S.C. $\S 286(2000)$.

95. See A.C. Aukerman Co. v. R.L. Chaides Constr. Co., 960 F.2d 1020, 1028-32 (Fed. Cir. 1992) (en banc).

96. See id. at 1033 (listing "negotiations with the accused [infringer]" as one factor to be considered in reasonableness of delay); $c f$. Gasser Chair Co. v. Infanti Chair Mfg. Corp., 60 F.3d 770, 774 (Fed. Cir. 1995) (describing negotiation of possible "settlement"/license as one factor in holding patentee's delay in bringing suit was not unreasonably long). 
long effective limitations period. This of course makes patent infringement attractive in cases where the plaintiff has delayed filing suit for an appreciable period of time.

Dataq, Inc. v. Tokheim Corp. ${ }^{97}$ is such a case. Dataq was a small company developing electronically-controlled gas pumps for filling stations. When a larger company called Tokheim expressed an interest in possibly acquiring Dataq, the two companies signed a confidentiality agreement. Dataq and Tokheim negotiated for two years, all the while exchanging information in the manner described in Part II above. Tokheim eventually backed out of the acquisition, however, and the nondisclosure agreement expired. When Tokheim introduced a product incorporating many of the features Dataq had invented and disclosed, Dataq filed suit for breach of contract and patent infringement.

Under the Oklahoma statute that applied to the case, a plaintiff has five years within which to file a contract claim. The nondisclosure agreement signed by Dataq and Tokheim expired by its terms in 1971, and the contract action was filed in 1978. Although Dataq argued that the statute should be tolled in this case for various reasons, the Tenth Circuit upheld the trial court's grant of defendant's directed verdict motion on the contracts claim. "The evidence produced at trial," the court wrote, "and any inferences drawn from it clearly supports the trial court's findings that the plaintiff was aware that 'something may have been amiss concerning the Defendant's obligations under the confidentiality agreement' by November of 1972."98 Thus, even with tolling, plaintiff would have had to file the contract action by 1977 to stay inside the limitations period.

The patent infringement action survived. Indeed, the Tenth Circuit reversed the district court's directed verdict for defendant on the infringement issue. ${ }^{99}$ The case was remanded for full consideration of the plaintiff's arguments regarding patent validity. For our purposes, the key point is simply that the plaintiff's infringement action gave it additional ammunition in pursuing relief from the violation of its contract with the defendant. $^{100}$

97. 736 F.2d 601 (10th Cir. 1984).

98. Id. at 604 (quoting trial record).

99. Id. at 604-05.

100. The same is true where a contract existed, but has been fully performed (or, presumably, terminated without breach). See, e.g., Cipes v. Mikasa, Inc., 379 F. Supp. 2 d 84 (D. Mass. 2005) (affirming copyright infringement finding where jury may have found that licensing agreement had run its course prior to infringement). 


\section{Breach of Contract Over Infringement: Strategy and Sample Cases}

Given the virtues of infringement suits, it might seem puzzling that anyone with a patent would prefer to sue for breach of contract. But contract suits have their advantages - two in particular. The most important is that a patent cannot be invalidated in contract litigation, whereas this is always a risk in a suit for patent infringement. A second advantage is that, assuming a plaintiff has decided to bring a contract cause of action, state courts may be preferred because they have much more experience with contracts issues. Research shows that $96 \%$ of all contracts cases are heard in state courts. ${ }^{101}$ Thus, a plaintiff may well seek out the higher contractsrelated expertise of a state court tribunal, rather than bring suit in federal court. Whatever their motivations, patentees sometimes choose to litigate in state courts. Federal courts by and large cooperate: defendants who attempt to remove these actions to a federal forum usually lose, as long as the plaintiff crafts the complaint so as to avoid direct consideration of patent validity or infringement.

In re Oximetrix ${ }^{102}$ is a case in point. A company called Shaw Associates (Shaw) had exclusively licensed its intravenous equipment technology-including "patented and unpatented inventions, prototypes, plans, trade secrets, know-how, and other information"-to Oximetrix. ${ }^{103}$ After eight years of working within the agreement, Oximetrix informed Shaw

101. See Marc Galanter; Contract in Court; or Almost Everything You May or May Not Want to Know About Contract Litigation, 2001 WIS. L. REV. 577, 585 (showing data regarding state and federal contracts filings where, as of 1998, state court filings numbered roughly 200,000 and federal court diversity filings roughly 8,000); see also NAT'L CTR. For STATE Courts, 2003 EXamining THE WORK OF STATE COURTS 23, 25 (examining recent trends in contracts case filings in state courts and showing contracts filings totaled more than 350,000 in the seventeen states whose data through 2002 are collected in the statistics), available at http://www.ncsconline.org/d_research/csp/2003_files/ 2003_subcivil-TORTCON.pdf; $c f$. Lawrence Gene Sager, Insular Majorities Unabated: Warth v. Seldin and City of Eastlake v. Forest City Enterprises, Inc., 91 HARV. L. REV. 1373,1424 (1978) ("[T] lution of zoning disputes."). Sager also describes:

$[T]$ he federal courts, after all, are inexperienced in land use litigation; they lack familiarity with local zoning processes, and with the infrastructure of state court zoning decisions, state enabling legislation, and state constitutional constraints, which in combination produce a package of zoning law and practice which may vary considerably from state to state.

Sager, supra at 1424.

102. 748 F.2d 637 (Fed. Cir. 1984).

103. Id. at 639. 
that it would no longer pay royalties. ${ }^{104}$ Shaw then sued for breach of contract in California state court. After a three month trial, the state trial court found Oximetrix to be in breach of the agreement and ordered it to pay damages to Shaw. Oximetrix asked for removal to federal district court on the ground that the suit involved issues of patent law appropriate only for the federal forum. The Federal Circuit upheld the district court's denial of the Oximetrix removal motion, pointing out that "the complaint [filed by Shaw] spoke only of contract claims. It said not a word about patent infringement." 105

Oximetrix also exhibits another favorable feature of state court actions for patentees. The court there enjoined Oximetrix from "using the patented inventions of the agreement, whatever may eventually be the fate of the patents." 106 Because the license in Oximetrix covered patented and unpatented technology, the state court crafted a remedy that effectively compensated Shaw for the misuse of both-without, of course, Shaw having to put its patents at risk of being invalidated. Other cases show that when patent and contract issues intertwine, patentee-licensors sometimes find state courts to be a very favorable forum. This was true in the California case of Seagren $v$. Smith, ${ }^{107}$ where a state court ordered relief for posttermination violations of a licensing agreement. (Normally, termination of a licensing agreement ends the contractual relationship, and with it any basis for prospective relief.) The court found the defendant liable "upon the theory of implied contract based upon the well-recognized and settled principle that a person shall not be permitted to enrich himself unjustly at the expense of another." 108 This prospective injunction against violation of its now-terminated agreement bears a striking resemblance to a state court injunction against patent infringement.

State courts in contract cases can occasionally do even more. At times they can help plaintiffs more than a federal court, with the help of careful contract drafting. A license agreement drafted before a patent application has issued may, for instance, give an inventor the right to royalties even if the application is rejected by the Patent Office. ${ }^{109}$ The same goes for a

104. To be precise, Oximetrix said it would only pay royalties on patented Shaw technology that Oximetrix was currently using-which, Oximetrix concluded, was $5 \%$ of their sales. Id.

105. Id. at 642 .

106. Id. at 641 (emphasis in original).

107. 63 Cal. App. 2d 733 (Ct. App. 1944).

108. Id. at 741 .

109. Beattie v. Prod. Design \& Eng'g, Inc., 198 N.W.2d 139, 141 (Minn. 1972) (holding issuance of patent was not a condition precedent to payment of royalties under an agreement for payment of $3 \%$ royalty "of the product or products covered by the 
well-drafted contract covering an application that ripens into a patent later found to be invalid. ${ }^{110}$ Notice that in such cases the patent becomes largely irrelevant after serving a "matchmaking" function. The parties are drawn into negotiations, under the penumbra of (potential) patent protection; once the parties reach an agreement, the ultimate validity of the property right becomes almost irrelevant. These "disappearing patents" lay bare the contract-facilitating face of patent law better than anything else.

\section{B. Summary: Enforcement Flexibility is in the Details}

The table below summarizes the respective advantages of patent infringement and breach of contract actions.

\begin{tabular}{|l|l|}
\hline Patent Infringement & Breach of Contract \\
\hline Higher Damages (sometimes) & Expertise of State Courts \\
\hline Attorney Fees (sometimes) & Patent Validity not at Risk \\
\hline No Privity Required & $\begin{array}{l}\text { Recovery Despite Abandoned } \\
\text { or Invalidated Patent } \\
\text { (sometimes) }\end{array}$ \\
\hline
\end{tabular}

\section{WHY SHOULD WE CARE ABOUT ALL THIS? THE TRANSACTION-INTENSIVE LANDSCAPE OF THE NEW ECONOMY}

All this matters because in the new economy, commentators expect the volume of transactions to increase dramatically. ${ }^{111}$ Headlines proclaim the

claims of the patent application"); Sunday v. Novi Equip. Co., 287 N.W. 909 (Mich. 1939) (holding that whether the patent finally issued was immaterial in an action for royalties under license contract).

110. See Heltra, Inc. v. Richen-Gemco, Inc., 395 F. Supp. 346, 351 (D.S.C. 1975) (interpreting South Carolina law and finding that parties intended royalties to be paid so long as "the basic concept of the ... apparatus purchased was used in producing the defendant's .... machines regardless of whether a patent covering the device subsequently issued or not."); see also Eno v. Prime Mfg. Co., 50 N.E.2d 401, 407 (Mass. 1943), and cases cited therein.

111. See Robert Pitofsky, Antitrust and Intellectual Property: Unresolved Issues at the Heart of the New Economy, 16 BERKELEY TECH. L.J. 535 (2001). Pitofsky writes:

The essential feature that is new about the "New Economy" is its increased dependence on products and services that are the embodiment of ideas. ... In each of these areas, the "product" or "service" is a piece of intellectual property such as a line of computer code, a new connect- 
era of outsourcing, downsizing, and "nimble firms." Theorists talk about the end of the twentieth century production model where most industries were dominated by a small handful of massive, fully integrated firms. ${ }^{12}$ In the new "modular" economy that some see emerging, many independent firms sell specialized goods and services that can be assembled and configured in different ways to meet the needs of various markets. Gone is the large, vertically integrated firm that gathered all the resources-physical, intellectual, and human-needed to produce a given item. ${ }^{113}$ This older type of firm was masterfully (and meticulously) described by Harvard's Alfred Chandler, the business historian par excellence. ${ }^{114}$ Thus the label given to the new, modular firms by a younger generation of scholars: PostChandlerian. As these theorists point out, these "dis-integrated" firms have replaced intra-firm coordination with firm-to-firm coordination. To revert to the language of Oliver Williamson, they replace centralized "hierarchies" with decentralized "markets." While there is some debate over the exact nature of coordination in the new modular economy, all agree that this way of doing things demands more firm-to-firm interaction-broadly Id. at 536.

ing device to make routers and servers more efficient, or new knowledge about genetic profiling that facilitates the use of gene therapy products to treat disease.

112. See, e.g., Naomi R. Lamoreaux et al., Beyond Markets and Hierarchies: Toward a New Synthesis of American Business History, 108 AM. HIST. REV. 404 (2003); Richard N. Langlois, Chandler in a Larger Frame: Markets, Transaction Costs, and Organizational Form in History, 5 ENTERPRISE \& SOC'Y 355 (2004); Richard N. Langlois, The Vanishing Hand: The Changing Dynamics of Industrial Capitalism, 12 INDUS. \& CORP. CHANGE 351 (2003).

113. See, e.g., Luigi Zingales, In Search of New Foundations, 55 J. FIN. 1623 (2000). Zingales explains:

[T]he traditional business corporation, which emerged at the beginning of the twentieth century . . . is a very asset-intensive and highly vertically integrated firm, with a tight control over its employees-control that is concentrated at the top of the organizational pyramid ....

Not any more. The nature of the firm is changing. Large conglomerates have been broken up, and their units have been spun off as stand-alone companies. Vertically integrated manufacturers have relinquished direct control of their suppliers and moved toward looser forms of collaboration. Human capital is emerging as the most crucial asset. As a result of these changes, the boundaries of the firms are in constant flux ....

Id. at 1624 .

114. See generally AlFRED D. ChANDLER, JR., SCALE AND SCOPE: THE DYNAMICS OF Industrial Capitalism (1994); Alfred D. Chandler, JR., THE Visible Hand: The MANAGERIAL REVOLUTION IN AMERICAN BUSINESS (1980). 
speaking, more transactions. When production is broken up and parsed out among more separate firms, transactions of some kind are required to assemble the components into a final product.

Transactions are not quite the same as contracts, however. For instance, some products can be designed so that one firm's component simply plugs into another. This "hard-wired modularity" reduces transactions to a simple matter of interface protocols. Not all products work this way, of course. When coordination cannot be engineered into components, and must be actively arranged, it can sometimes be achieved informally without resort to legally enforceable contracts. The Japanese industrial groups, keiretsu, are comprised of individual firms that operate quite effectively together without formal legal bonds. A large body of "institutional" economics studies similar arrangements. ${ }^{115}$ This research shows how rules emerge to govern interactions among economic actors who deal with each other repeatedly. These rules range from binding laws and contracts to informal norms; the only constant is that they provide effective governance and incentive systems for individual actors.

Thus, contracts are not necessarily required for firms to interact effectively; so too with property rights. In some settings, economic institutions take shape without the presence of formal property rights. De facto or informally recognized claims - what might be considered "quasi-property" rights - are enough to get things going. The standard example is municipal water districts, as described in the pioneering research of Elinor Ostrom. ${ }^{116}$ Recently, several scholars have argued that medieval craft guilds exhibited some of the same characteristics, including a foundation in informallyrecognized "trade secrets." 117 In other cases, property rights are essential to institutions. Patent pools and standard-setting organizations are good examples, as are "collective rights organizations" that assemble copyrights for blanket licensing to the radio and TV industries.

115. See, e.g., Networks ANd ORganizations: Structure, Form, AND ACTION (Nitin Nohria \& Robert G. Eccles eds., 1993). On the keiretsu, see MiCHAEL L. GERlaCh, Alliance Capitalism: The Social Organization of JaPanese Business (1997).

116. Elinor OStrom, Governing the Commons: The Evolution of INSTITUTIONS FOR COLLECTIVE ACTION (1990).

117. See Stephan R. Epstein, Property Rights to Technical Knowledge in Premodern Europe, 1300-1800, 94 AM. ECON. REV. 382 (PAPERS \& PROC.) (2004); Robert P. Merges, From Medieval Guilds to Open Source Software: Informal Norms, Appropriability Institutions, and Innovation (Nov. 13, 2004) (working paper), http://papers.ssrn.com/ sol3/papers.cfm?abstract_id=661543; see also S.R. Epstein, Craft Guilds, Apprenticeship, and Technological Change in Preindustrial Europe, 58 J. ECON. HIST. 684, 688-93 (1998). 
This brief survey of institutions has one point: when it comes to harnessing the work of disparate firms, property rights and contracts are not the only games in town. Institutions emerge from all sorts of backgrounds. This has been true in the past, and will no doubt continue to be true as the new economy takes shape. Even so, some firms will handle the increased need for coordination with formal contracts. ${ }^{118}$ And some of these will be helped along by formal property rights. In other words, these formal legal instruments are not the only way for firms to effectively interact; but they are tried and true ways. We can expect that they will be pressed into service with increasing frequency in the new economic landscape. Whether they will be the dominant form of "private ordering"-as some believe they were in the pre-Chandlerian era-is not for me to answer. I am confident that they will increase in importance. That is enough to justify my attention in this Article to the way they interact.

A few diagrams may help clarify the point. The figure below represents a typical "old economy" scenario, with Firm A buying something from Firm B. A wholly owned division of Firm B is assigned the task of adapting Firm B's product to the needs of Firm A. (Think of Firm B as selling an assembly line component that must be integrated into Firm A's complex assembly line.)

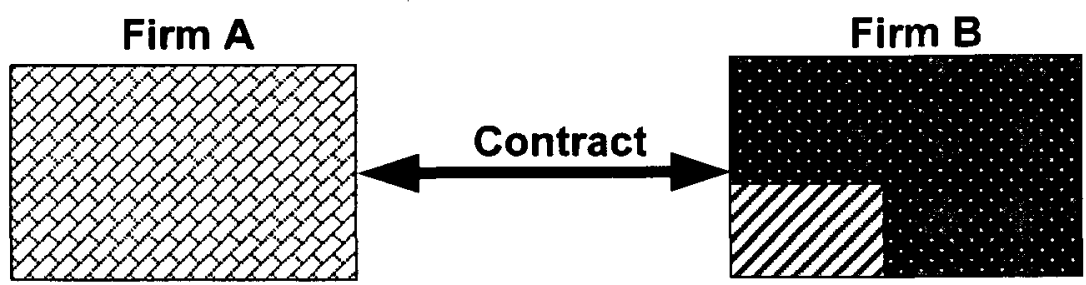

Division

118. These institutions typically take shape over time among firms that repeatedly interact with each other. They are therefore not available to non-repeat players, or to firms that are first beginning to do business together. Secondly, the norms and other "rules of the game" for these institutions are often fairly "soft" constraints. While they work at times under some circumstances, they are not always as reliable as contracts. Take the example of open source software, in many ways today's most visible experiment in informal coordination. Open source has an uncertain future, despite the loyalty of many programmers who contribute their time and energy. The norms that hold these communities together are in some ways fragile. The entry of for-profit firms may affect the willingness of firms and individuals to continue their participation. Private firms do contribute to open source projects, but they have their own strategic reasons for doing so. 
Now imagine that Firm B has "downsized," by "spinning off" this division as a separate firm, Firm C. Firm B now "outsources" the work formerly done by its division to this new Firm $C$. Because Firm $C$ will be privy to sensitive information about both Firm A's assembly line and Firm B's manufactured components, and because Firm $\mathrm{C}$ may consider its adaptation techniques and technologies proprietary, it will enter into agreements with both Firm A and Firm B. As the primary buyer and the primary seller, respectively, Firms A and B will probably still want to enter into a contract with each other. The upshot for our purposes is an additional set of transactions, as illustrated in the following figure.

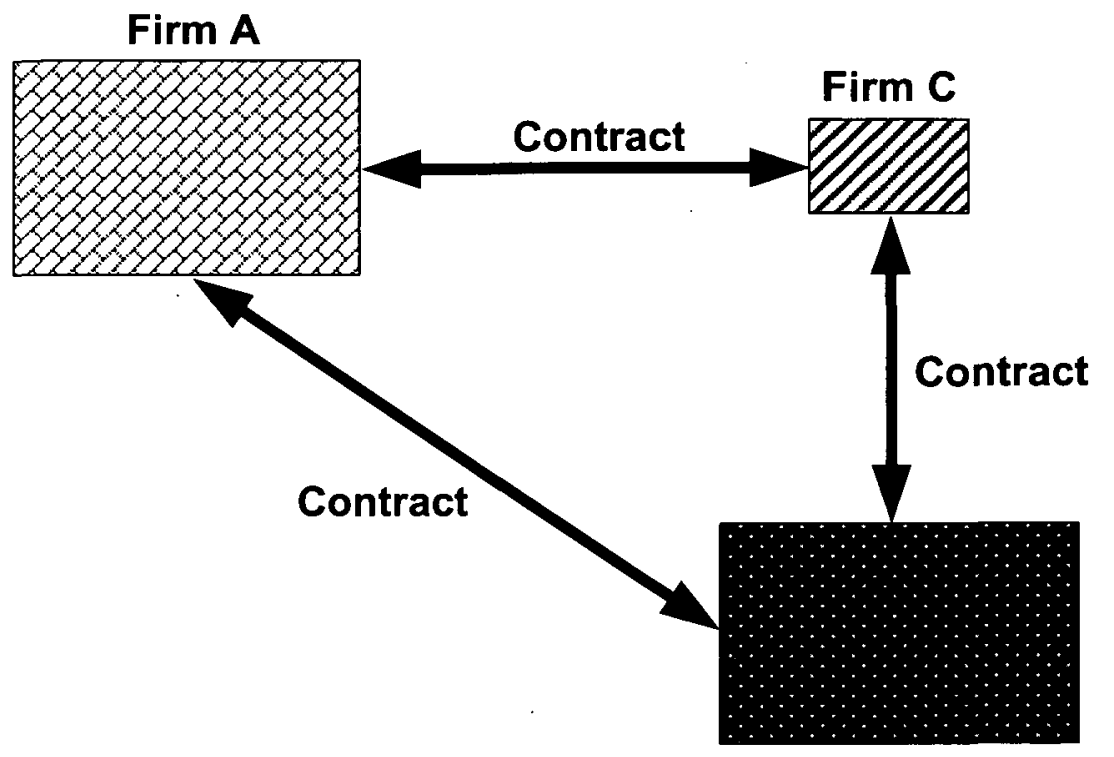

Firm B

This schematic illustration of what might be called the "disintegration" of production describes a reality playing out in scores of industries in the contemporary economy. An early pioneer in this regard was the microcomputer or PC industry, which progressed from old-style vertical integration to a market structure epitomized by Dell Computer. Though it is a large brand-name retail entity, Dell does not own many manufacturing assets. Rather, Dell buys and assembles components from dozens of specialty suppliers. ${ }^{119}$ Some segments of the semiconductor in-

119. For a pioneering study of these developments, see Richard N. Langlois \& Paul L. Robertson, Networks and Innovation in a Modular System: Lessons from the Microcomputer and Stereo Component Industries, 21 RES. POL'Y 297 (1992), reprinted in MaNAGING IN THE Modular Age: ARChITECTURES, Networks, AND ORganizations (G. Raghu et al. eds., 2002) (innovation in a modular system can lead to vertical and hori- 
dustry have changed along these lines as well. What used to be a uniform landscape of large, integrated firms now looks quite different: some firms, so-called "foundries," specialize in manufacturing and other firms, socalled "fabless" design firms, specialize in component and chip design. ${ }^{120}$ Pharmaceutical research is a third example. Today large pharmaceutical companies contract with dozens of smaller research-intensive firms, many in the biotechnology industry, to develop specific products. ${ }^{121}$. Some have argued that this industry is the harbinger of an entirely new mode of corporate organization - the "network firm." 122 However one chooses to describe it, the industry is a far cry from the days when most research took place in centralized divisions wholly owned by the parent company. ${ }^{123}$

zontal disintegration, as firms can often best appropriate the rents of innovation by opening their technology to an outside network of competing and cooperating firms). On Dell Computer Corporation, see Joan Magretta, The Power of Virtual Integration: An Interview with Dell Computer's Michael Dell, HARv. Bus. REV., Mar.-Apr. 1998, at 72-85, which describes Dell's "virtual integration" model-close working relationships between Dell and its many component suppliers that allow many of the benefits of the old vertical integration model without the "drag of ownership" that the old model entails.

120. "Fabless" refers to the absence of "wafer fabrication" (for example, semiconductor chip manufacturing) capabilities within these firms. See, e.g., Bronwyn H. Hall \& Rosemarie Ham Ziedonis, The Patent Paradox Revisited: An Empirical Study of Patenting in the U.S. Semiconductor Industry, 1979-1995, 32 RAND J. ECON. 101, 107 (2001). The fabless portion of the semiconductor industry has undergone significant growth in recent years. See, e.g., GLOBAL-ELECTRONICS.NET, Fabless Firms Take 17 Percent of Q2 [2005] Chip Market, http://www.global-electronics.net/id/23265/CMEntries_ID/105295 (last visited Nov. 20, 2005) (trade publication describing industry trends). Also, see generally the website for the Fabless Semiconductor Association, an industry trade group, at http://www.fsa.org (last visited Dec. 2, 2005). For an example of how a foundry operates, see JiM TURLEY, THE ESSENTIAL GUIDE TO SEMICONDUCTORS 98 (2003) (describing the Taiwan Semiconductor Manufacturing Corporation (TSMC), a large foundry firm in Taiwan).

121. See, e.g., Josh Lerner \& Robert P. Merges, The Control of Technology Alliances: An Empirical Analysis of the Biotechnology Industry, 46 J. INDUS. ECON. 125 (1998). The biotechnology industry generates so many inter-firm technology collaborations that a specialized firm called Recombinant Capital runs a successful business selling information about industry contracts. See www.recap.com (last visited Dec. 9, 2005).

122. See, e.g., Networks AND ORGanizations: Structure, Form, AND ACtion (Nitin Nohria \& Robert G. Eccles eds., 1993). On the complex patterns of the contemporary biotechnology industry network, see Walter W. Powell et al., Network Dynamics and Field Evolution: The Growth of Interorganizational Collaboration in the Life Sciences, 110 AM. J. Soc. 1132 (2005).

123. See Louis Galambos \& Jeffrey L. Sturchio, Pharmaceutical Firms and the Transition to Biotechnology: A Study in Strategic Innovation, 72 BUS. HIST. REV. 250, 252 (1998) ("During the 1930s, 1940s, and 1950s, for example, it was large, vertically integrated companies that led the industry into the golden age of medicinal chemistry. The 
For my purposes, this trend matters because it points to an increase in the number of arm's-length transactions. More and more firms that were divisions of other firms, or would have been under the old production model, are now independent. Stages of production that formerly were coordinated from within a single large firm are being broken up and spread across more firms. Interactions governed in the past by internal firm fiat are being replaced by arm's-length contracting. The new economy is simply much more transaction-intensive than the old one it is quickly replacing.

This suggests a larger role for property rights. For all the reasons documented in Parts II and III above, property rights play an important role in facilitating contracting. They make it easier for the welter of firms to approach one another and begin early-stage disclosure and negotiation. They provide more remedial options and more secure safeguards after a contract is signed. All of which eases the contracting process that is so crucial to economic activity in a more dis-integrated industrial landscape.

\section{CONCLUSION}

In an economy where contracting is becoming more pervasive, property rights invest contractual exchange with an important dimension. At the initial stage, they facilitate precontractual negotiations. After parties sign a contract, property rights give contracting parties numerous additional enforcement options which, in the aggregate, confer considerable flexibility. In sum, they are valuable adjuncts at every stage of the contracting process.

After all this talk of hard-headed economic rationality, let me end with some observations on anonymity and intimacy. Property rights bring the power of the state to bear on relations between legal "strangers." By specifying a holder's rights "against the world," they create an off-the-rack, mandatory legal relationship between the right holder and everyone else. Contracts are completely different. A contract signifies a close, voluntary relationship between assenting parties - what one might call a legally "intimate" relationship. What I have been trying to do in this Article is to first describe how property works in the hinterland, the transition zone, between legal strangers and legal intimates. Next I have shown how, once parties cross the bridge between the anonymity of property and the intimacy of contract, property continues as an important presence in the relationship. Property ownership gives a contracting party many small addi-

later transition into microbial biochemistry/enzymology followed a similar pattern.") (footnote omitted). 
tional options that become collectively valuable if the contract goes badif enforcement becomes necessary. And so the power of the state-backed property right continues to exert influence even after legal actors are no longer strangers.

Viewed in this light, property and contract are no longer a dichotomous pair. They can be seen to work together toward a common end: the promotion of voluntary, bilateral contracting. Given the rising importance of contracts in the new economy taking shape around us, this harmony at the heart of two of our most basic legal categories seems an important discovery indeed. 